\title{
Control factors of Holocene sedimentary infilling in a semi- closed tidal estuarine-like system: the bay of Brest (France)
}

\author{
Gregoire Gwendoline ${ }^{1,2,{ }^{*}, \text { Le Roy Pascal }}{ }^{1}$, Ehrhold Axel ${ }^{2}$, Jouet Gwenael ${ }^{2}$, Garlan Thierry ${ }^{3}$
}

${ }^{1}$ Institut Universitaire Européen de la Mer, UMR 6538 Domaines Océaniques, Technopôle Brest-Iroise, 29280, Plouzané, France

2 IFREMER, Géosciences Marines, Centre, de Brest, BP70, CS10070, 29280 Plouzané, France

${ }^{3}$ SHOM, Centre Hydrographique, BP426, 29275, Brest, France

* Corresponding author : Gwendoline Gregoire, email address : gwendoline.gregoire@ifremer.fr

pascal.leroy@univ-brest.fr ; axel.ehrhold@ifremer.fr ; gwenael.jouet@ifremer.fr ; Thierry.garlan@shom.fr

\begin{abstract}
:
This study details the sedimentary infilling of an original tidal-dominated estuary system during the final stage of the last marine transgression. The Bay of Brest is confined and connects the rivers Elorn and Aulne, to the sea of Iroise by a narrow strait encasing a well preserved paleo-channel. The compilation of high- and very-high-resolution bathymetric and seismic data, constrained by sediments datations, allows us to classify the paleo-morphology of the bay into three stepped domains: the paleo-valley floor surrounded by fluvial terraces, the central plateau, and the shallow embayments. Taking into account the main factors controlling the infilling, including sea-level rise, substratum morphology, and hydrodynamics, the stratigraphic scheme of the bay has been reconstructed. The lowstand system track (LST) is assumed to correspond to relict Pleistocene continental deposits associated with the last low sea level around $21,000 \mathrm{cal}$ yr B.P. The transgressive phase, represented by the transgressive system track (TST), is divided into two parts. The lower part (TST1) constitutes the first stage of transgressive deposition in the bay. Starting around $9000 \mathrm{cal}$ yr B.P. and currently conserved in the shallowest parts, it is characterized by tidal flats associated with deposits in the inner estuary. This stage ends at about $7000 \mathrm{cal} \mathrm{yr} \mathrm{B.P.} \mathrm{and} \mathrm{is} \mathrm{separated} \mathrm{from} \mathrm{the} \mathrm{upper} \mathrm{part} \mathrm{(TST2)} \mathrm{by} \mathrm{a} \mathrm{tidal} \mathrm{ravinement} \mathrm{surface} \mathrm{that} \mathrm{occurs}$ around $7700 \mathrm{cal}$ yr B.P. at the foot slope. TST2 formed sand bodies in the central part of the bay between 6800 and $3000 \mathrm{cal}$ yr B.P. These deposits, interpreted as tidal banks, are associated with the outer estuarine environment. The maximum flooding surface (MFS), dated around 3000 and $2000 \mathrm{cal}$ yr B.P., marked the installation of a highstand system track (HST) under the combined influence of tidal currents, storms events, and anthropogenic activity. The geometry deposition of each system track is controlled at the first order by the combination of the irregular Holocene sea level rise and the inherited rocky substratum morphology. The retreat of the shoreline, and estuarine environments, is function of the successive flooding of stepped domains. The direct evolution of the volume of the assumed accumulated sea water in the bay favoured the gradual installation of the present-day hydrodynamic circulation.
\end{abstract}




\section{Highlights}

- Sedimentary records retrace the landward retreat of tidal processes at the Holocene. The stepped bedrock allows unique preservation of depositional environments. The bed-rock morphology has a key-role on the conservation of sediment deposition.

Keywords: Tide-dominated estuary, incised-valley, holocene infill, seismic stratigraphy, estuarine processes, Bay of Brest

\section{Introduction}

Modern estuaries constitute key areas for the preservation of sedimentary deposits related to the Holocene period. Located at the land-sea transition, their sedimentary records establish an archive of environmental evolution in the context of marine transgression. Classified by their morphology (Perillo, 1995; Ryan et al., 2003; Dalrymple, 2006) and physical parameters (Pritchard, 1955; Fischer, 1976), they are very diverse. Although sea-level is one of the main factors controlling estuary infilling, it remains a combination of sea level together with the impact of hydrodynamics, sediment supplies, and bedrock morphology. During the 1990's, interest grew 
for the study of estuaries and incised-valleys, due to the well-conserved deposits constituting a potential oil reservoir (Posamentier and Allen, 1993; Zaitlin et al., 1994; Dalrymple, 2010). These studies have highlighted the importance of the control of system parameters of the sedimentary deposits (Chaumillon et al., 2010). The case of the tide-dominated estuary, although less studied, is a good example of sedimentary preservation, partly because of its location at the land-sea transition (Dalrymple et al., 1990; Jouet et al., 2003; García-García et al., 2005; Billeaud et al., 2007; Menier et al., 2010; Proust et al., 2010; Dalrymple et al., 2012; Tessier et al., 2012; Traini et al., 2013; Green et al., 2013; Zhang et al., 2014).

However, the tidal accommodation that controls the infilling of the bay prevents the upstreamdownstream read of the system and the longitudinal variability is always poorly understood (Dalrymple et al., 2012). The morphological configuration of the confined Bay of Brest offers a unique opportunity to improve the understanding of macrotidal sedimentary environments. The isolated tide-dominated estuary system is indeed sheltered from the waves by a narrow strait, preserving shallow tidal deposits from coastal erosion. Numerous sedimentological and geophysical data collected in the area allow us to study in details the sedimentary record from the coast to the paleo-valley in order to (1) determine the main controlling factors of the sedimentary infilling, (2) determine the landward retreat of the estuarine processes during the Holocene, and finally (3) establish the timing and the role played by the installation of the present-day hydrodynamic circulation on the sediment redistribution.

\section{Regional settings}

\subsection{Geology and oceanography}

The Bay of Brest, located in the most western part of Brittany (France), constitutes an original confluence of two estuary systems (Aulne and Elorn) covering an area of $181 \mathrm{~km}^{2}$ and connected to the Atlantic Ocean (Iroise Sea) by the Goulet (a narrow strait of one nautical mile wide) (Fig. 1). 
Its $250 \mathrm{~km}$-length jagged coastline includes various sheltered and shallow areas $(<10$ meters water depth), where embayments and coves represent $40 \%$ of the Bay of Brest. Most of them are characterized by tidal flats surrounding a deeper axial channel network. The bay corresponds to a submerged drainage system oriented in the continuity of the main rivers: Aulne and Elorn. The two river channels converge to the center part of the bay where they merge and form a large valley in the Goulet area (57 meters Below Lower Astronomical Tide (BLAT)) (Fig. 1). The structure of this network is consistent with the substratum geology controlled by an inherited fault system (the Elorn Fault, satellite of the CNA for Cisaillement Nord Armoricain), with a general trend of $\mathrm{N}^{\circ} 70$, and separating two regional geological domains (Fig. 1). Granitic and metamorphic hercynian rocks and Precambrian (Brioverian) sedimentary rocks form the north domain, whereas the south, which is the whole rocky basement of the bay, is mostly composed of Paleozoic sedimentary rocks (Brioverian to Paleozoic) (Babin et al., 1969; Garreau, 1977, 1980; Ballèvre et al., 2009; Ballèvre et al., 2014, Le Gall et al., 2016). This main structural direction is intersected by $\mathrm{N}^{\circ} 140$ trending fault (Kerforne), reactivated during the Atlantic opening (Fig. 1).

The present-day morpho-sedimentary cover allows us to distinguish three main areas in the Bay of Brest: (1) the central bay characterized by coarse bio-lithoclastic sediments becoming finer towards the estuaries, (2) the Elorn mouth at the north, and (3) the Aulne mouth in the south. Both are characterized by large tidal flats covered by a muddy fraction mixed with coarser sediments mainly composed of shells (Crepidula) and red algae debris (Maërl) (Gregoire et al., 2016). Currently, the morpho-sedimentary partitioning is mainly maintained by tidal currents, with a tidal range of 4.7 meters (semi-diurnal), and fluvial hydrodynamics. The limited width of the bay entry mainly impacts the hydrodynamic circulation in two ways: (1) it generates, by the Venturi effect, a strong tide current reaching speeds of up to $9 \mathrm{~m} / \mathrm{s}$ in spring tidal conditions, and (2) it limits swells influence. Thus, marine hydrodynamics are largely dominated by tidal currents ranging from 0.25 to $2 \mathrm{~m} / \mathrm{s}$. The main fluvial supply comes from the Aulne river with a sedimentary contribution of 7,000 (tonnes/year in dry weight) and a water discharge four times 
higher $\left(22 \mathrm{~m}^{3} / \mathrm{s}\right)$ than the Elorn river (Bassoulet, 1979; Auffret, 1983). However, due to local winds the sea could be rough and affects the superficial mass water. Thus, waves with a weak wavelength and strong steepness can reach the shore with high obliquity (Pommepuy, 1977).

\subsection{Network formation and paleo-sedimentology}

During the 1970s and 1980s, pioneering studies contributed to the characterization of the incised valleys in the Bay of Brest and their extension to the adjacent open sea (Hinschberger and SaintRéquier, 1970; Fichaut, 1984). Recent studies enabled the partial reconstruction of the paleofluvial network from the first incision to the present-day (Hallégouet, 1994; Baltzer at al., 2010). During the Tertiary, the first fluvial network was incised a flat surface and flowed toward the NW in the actual Penfeld River (Fig. 1). The true genesis of the bay begins in the late Oligocene. At this time, a stream, evolving by regressive erosion in a narrow corridor (the present day 'Goulet') along the CNA fault (Cisaillement Nord Armoricain), captured the Aulne and Elorn rivers (Hallégouet, 1994). The resulting network was oriented toward the WSW in the direction of the Iroise Sea. In parallel, a secondary network formed in the depression of the Plougastel-Daoulas peninsula (Garreau, 1980). The digging of the bay was accentuated by the Pleistocene eustatic variations. During each glacial-interglacial cycle, sedimentary records were largely eroded and the low preservation interval from one highstand to another one was facilitated by the nonsubsidence of the bay. The channels' backfill is assumed to be partly composed by periglacial heads deposits dated from the last glacial episode, around $30000 \mathrm{cal}$ yr B.P (Morzadec-Kerfourne, 1974). Recent studies have been conducted (Stéphan, 2010; Goslin et al., 2013, Fernane et al., 2014; Goslin et al, 2015; Stéphan et al., 2015) in the marshes surrounding the bay in order to evaluate the Holocene deposits. The micro-fauna assemblages and peat analyses (organic ${ }^{14} \mathrm{C}$ dating) show that during the Holocene period the Bay of Brest evolved non-uniformly from a continental to a marine environment. The stratigraphic succession is characterized by continental 
peats (6400 and $4500 \mathrm{cal}$. B.P at the base) buried by salt-marsh deposits (4500-3600 cal. B.P) and covered by a modern-day layer (2700 cal. yr B.P to present-day).

\section{Materials and methods}

The present study is based on a combined approach involving high- and very-high-resolution seismic data correlated to cores (Fig. 2a). These data were obtained during the SERABEQ surveys between 2014 and 2015. To complete the new dataset, seismic profiles from older campaigns (1986-2013) have been reprocessed and reinterpreted.

\subsection{Geophysical data}

90 kilometers of high resolution seismic profiles were gathered during the SERABEQ 1

campaign in 2014, performed onboard the IFREMER R/V Thalia, and 423 kilometers of profiles have been acquired by several teaching surveys carried out by the University of Western Brittany (Brest) on board the Albert Lucas (GEOBREST 2009, 2010, 2011, 2012, 2013, and GEOLUCAS 2009, 2015). The former re-interpreted seismic profiles were recorded during the SAMDISOIR survey in 1992 (162 km of profiles). All these acquisitions were performed using a single-channel $\left(\mathrm{SIG}^{\mathrm{Q}}\right)$ streamer and a SPARKER source: dominant frequency is around $400 \mathrm{~Hz}$ enabling a vertical resolution of $1 \mathrm{~m}$. Data were recorded in the "SegY" format with the DELPH acquisition system $^{\odot}$ (developed by IX blue). In addition, $378 \mathrm{~km}$ of very-high resolution seismic profiles were recorded in the shallowest parts of the study area, with a depth range of between 10 and 2 meters, during the SERABEQ 2 survey (2015) on board the IFREMER vessel Haliotis equipped with a sub-bottom profiler (Chirp). These data sets were completed with several training surveys of the launch (HALIOTEST1 and HALIORADE) and with the REBRADE13 survey in 2013 (Fig. 2a). The Chirp pulse bandwidth from between 1.7 to $5.5 \mathrm{kHz}$ and allows a theoretical vertical resolution of up to $30 \mathrm{~cm}$. Raw data were processed by the $\mathrm{SUBOP}^{\odot}$ software (developed by IFREMER). 
In total, more than $1200 \mathrm{~km}$ of seismic profiles cover an area from the proximal areas in the main estuaries (Aulne and Elorn rivers) to the confined areas of the Bay of Brest, to the open sea area (Fig. 2a). All seismic lines were visualized, correlated, and interpreted with Kingdom Suite software (Seismic microtechnology INC ${ }^{9}$ ), using seismic stratigraphy principles (Mitchum et al., 1977; Vail et al., 1977). They are displayed in two-way travel time in ms and all the depth references are expressed in Below Astronomical Tide (BLAT). The correlation between core data and seismic profiles is based on a mean velocity of $1,800 \mathrm{~m} / \mathrm{s}$ for a depth-conversion of unconsolidated, mainly coarse-grained sediment (Cressard et Augris, 1981; Menier et al., 2010; Proust et al., 2010).

\subsection{Sediment analyses and AMS dating}

Five cores collected in the Bay of Brest during the SERABEQ 3 surveys (April 2015) by Kullenberg (IFREMER R/V Thalia) are presented. The cores, with lengths between 1 and 3.5 meters, were analyzed in our laboratory. The PVC liner was longitudinally cut in half for sampling and core description. Although rather short, they allowed us to calibrate the sedimentological facies of the superficial deposits.

The AMS ${ }^{14} \mathrm{C}$ measurements were conducted at the Poznan radiocarbon laboratory (Poland). Analyses were performed on $\mathrm{CaCO}_{3}$ on marine shells (bivalve mollusks and turritellas) sampled in life position and from the bulk of benthic foraminifera. Calib Rev 7.0.4 software (Stuiver et Reimer, 1993) was used to calibrate the ${ }^{14} \mathrm{C}$ ages using the "Intcal13" calibration curve (Reimer et al., 2013), with a confidence level of $95 \%$ for the standard deviation (sigma 2). We assumed a marine reservoir correction of 325 years in the Bay of Brest (Tisnérat-Laborde et al., 2010) (table 1).

\section{Results}


All these data has permitted us to depict the last glacial landscape of the Bay of Brest (paleovalley and substratum morphology) and the holocene sedimentation that followed.

\subsection{The substratum morphology}

By removing the sediment stacking, a digital terrain model (DTM) of the seismic substratum has been designed for the Bay of Brest and for the connected opened sea area, localized between the Bay of Bertheaume and Camaret (Fig. 3). Because of the presence of a gas blanket on seismic imagery (Fig. 3), some parts of the substratum could not be observed. The substratum morphology of the bay is characterized by a succession of three stepped domains called T1, T2 and T3 (Fig. 3). They can be interpreted as large terraces separated from each other by escarpments with elevations reaching up to 5 meters. The first step is linked to the valley activity and bounds the deeper incision on either side. This terrace mainly developed in the opened sea area at 30 meters deep where it can be individualized locally over lengths of 1000 meters (Fig. 3). The second stepped domain is wider, with a slightly steeper slope than the previous one. It corresponds to the major part of the substratum between 25 to 20 meters deep. This domain is larger toward the open sea (2,500 meters large in the bay to 3,500 meters in the open sea area). This terrace is incised by numerous gullies lying perpendicular to the main valley. Finally, the third stepped domain corresponds to the shallow sector (from $16 \mathrm{~m}$ deep to the present-day shoreline) and forms the embayments and coves restricted to the Bay of Brest. Numerous gully heads incise this terrace and extend deeper into the main channel (Fig. 3).

The paleo-fluvial network extends from the actual river estuaries to the Iroise Sea. The channel depths decrease at the rivers mouths (from 60 to 30 meters depths) and its morphology changes at the connection with both estuaries (Fig. 3). In the south, the Aulne's meandering paleo-valley flowed toward the north-east and the central basin (Sinuous Index SI about 1.15). In the north, the Elorn paleo-channel system appears linear probably controlled by the presence of a NE-SW trending fault bounding the northern side of the bay. In the Goulet, although the channel is 
narrow (maximum 500 meters), the incision is deep (60 meters) and surrounded by high cliffs (about 50 meters from the bottom of the paleo-valley). Seaward, the central valley becomes wider and less incised where it intersects the major regional SE-NW structural feature (Kerforne fault) (Figs. 1 and 3). A secondary network, corresponding to a previous fluvial pattern was incised by the main system. More developed in the south (Aulne), the meanders it forms are less clear than the native line. It reaches a maximum depth of 30 meters versus 35 meters in the principal axis. Towards the harbor, the Elorn channel is divided into two branches that merge westward at the confluence with the Aulne channel. In the Iroise Sea, a meander could result from this zone of tectonic weakness that affects the linear trend of the network (Garreau, 1977; Ballèvre et al., 2014).

\subsection{Seismic stratigraphy and local distribution}

The seismic profiles study reveals a stacking pattern for analyzing the reflection changes in frequency, amplitude, continuity, and their internal configuration, summarized in figure 4. Gas accumulation and probably coarse-grained deposits (sand to pebbles) disturb the acoustic signal in many places. This acoustic mask is especially well-developed in the shallowest flat area of the bay (Fig. 3). Nevertheless, it was possible to distinguish fourteen seismic facies gathered in four units, named from the bottom (U0) to the top (U3). These are illustrated on selected profiles and fence diagrams characterizing the Aulne valley infill (Figs. 5 and 8), and the estuarine Elorn deposits (Figs. 6 and 7) and located on figure 2.

Unit $0(\mathrm{U} 0)$ is characterized by medium to high frequency, high amplitude, and low continuity reflectors (Fig. 4). It displays a chaotic to sub-parallel internal configuration and is essentially localized in paleo-valleys, where it reaches 5 to 10 meters of thickness, and accumulates locally in the form of internal terraces (Figs. 5, 6 and 9). 
Unit 1 (U1) covers the acoustic basement of the embayment (average thickness of 5 meters). It also overlays the unit below, U0, on the Elorn terraces (Figs. 6 and 9) and occurs in some meanders of the main axis with a thickness up to 10 meters (Figs. 5 and 6). A strong reflection marks the discontinuity (D1) between U0 and U1. The acoustic signal of this unit differs in function of its location: embayment (F1e) or paleo-valley (F1p). In the embayments, the seismic geometry shows an aggrading set of parallel reflectors that presents medium frequency and high amplitude and continuity (Figs. 4,and 6). Locally, some cut and fill patterns can be observed through the embayment. Within the paleo-network, the F1p1 facies mostly grade into parallel and continuous oblique reflectors prograding and aggrading across the channels with high frequencies and amplitudes. Some chaotic facies are also observed (F1p2) (Fig. 6). The seismic subfacies located along the bank of the paleo-valley can be also organized in a remarkable set of parallel aggrading reflectors with medium to high frequencies and high amplitudes and continuities (F1p3) (Fig. 7).

Unit 2 (U2) was deposited in an erosional discontinuity marked by a strong reflection (D2). It has a larger extension through the bay with significant thicknesses variations. It can reach 15 meters in the paleo-valley (Fig. 9) but its mean value is closer to 5 meters. It presents some erosional channels above the embayment and sharp erosion from both side of the paleo-valley (Fig. 6). As for U1, the acoustic facies differ according to the seismic unit location (Fig. 4). In the embayment, the F2e facies presents two different subfacies. F2e1 is characterized by slightly oblique prograding reflectors with medium frequencies and continuities and high amplitudes. In contrast, the F2e2 facies shows parallel aggrading reflectors of high frequencies and medium amplitudes and continuities. U2 also constitutes the main part of the paleo-valley infill and it can be divided into four facies (F2p1, F2p2, F2p3, and F2p4). F2p1, F2p2, and F2p3 correspond to the core of the modern tidal bank identified on bathymetry (Fig. 6). They have the same acoustic characteristics, with medium frequencies and high continuities and amplitudes, but their own internal reflector configurations. At the base, the F2p1 subfacies shows oblique prograding 
reflectors, overlaid by F2p2, which aggrades with parallel reflectors and is directly covered by sigmoidal progradational reflectors (F2p3). The F2p4 subfacies shows oblique reflectors prograding with high frequencies and medium amplitudes and continuities. Thin, draping Unit 3 (U3) is located above an erosional discontinuity (D3) (Figs. 5 and 6). It presents aggrading parallel reflectors with low frequencies and amplitudes and medium continuities (Fig. 4). In some places, it can be confused with the thickness of sparker seismic signals at the top of the records, but its presence is confirmed by the ultra-high resolution chirp seismic profiles (Fig. 6). It is located throughout the entire bay but is more largely widespread over the tidal flats (Fig. 9).

Thus, the greatest sediment thickness is located in the paleo-channel with a maximum of 25 meters thick in front of the harbour, but also along the western and eastern channel rims in the central part (Fig. 9). In the Aulne estuary, only the meanders of the secondary network are filled. All embayments have sedimentary infill ranging from 5 to 10 meters, while deposits are absent or very thin $(<1$ meter $)$ across the central terrace.

\subsection{Core Analysis}

Five representative cores (SRQ3-KS02; KS-34; KS-39; KS-41; KS-44) located in key parts of the Bay of Brest (Fig. 10) were selected to constrain the seismic facies to establish chronostratigraphic scenario.

The cores SRQ3-KS02, KS-41, and KS-44 are correlated with the SRQ-70012 seismic profile (Fig.2) which is perpendicular to the Elorn paleo-valley and extends from the Corbeau bank to the channel central axis. The KS02 (water depth of -22 meters) is located within the channel, KS 41 (-12 meters) on the south flank of the paleo-valley and KS44 (-9 meters) on the Corbean bank..

SRQ3-KS02 is a short core (1.45 meters) constituted by fine sand associated with debris of seashell and Turitella. A thin layer $(10 \mathrm{~cm})$ of shelly coarser sand $(1.05$ meters depth in the core) is interpreted as the separation between the seismic U3 (upper part) of the core and U2 (bottom 
part) (Fig. 10). SRQ3-KS41 is situated on the southern rim of the estuarine axis (Figs. 2 and 10). The upper $60 \mathrm{~cm}$ of the core is topped by a thin silty layer covering gravels and overlying a mud bed gradually upgrading into coarse sand. This succession is associated with the seismic U3. Deeper, the sediment is constituted by a mixed mud alternating with rich-organic layers characteristic of the seismic U1.

SRQ3-KS44, located on the Corbeau bank, is representative of sediment accumulations on the shallowest part of the bay (Fig. 2) (less than 9 meters of depth). The upper part, corresponding to the seismic U3, is characterized by very fine sediment enclosing a thick shelly bed. Another shelly layer of $20 \mathrm{~cm}$, located at $130 \mathrm{~cm}$ below the top, divides the core in two parts and rests on a silty facies with occasionally rich-organic laminae. The lower facies is correlated with the seismic U2 (Fig. 10).

SRQ3-KS39, located on the SRQ-20010 line, samples the seismic units U1 to U3 (Figs. 2 and 10). It allows us to define the infilling along the slope limiting the tidal flats. The upper part of the core is characterized by a sandy mud alternation with fine sand beds, including debris of seashells and calcareous algae (maërl). The latter, interpreted as a seismic U3, is separated from deeper facies by an erosional surface at 95 centimeters under the top of the core (D3). Below, a layer $(30 \mathrm{~cm})$ constituted by a medium sand matrix mixed with seashell debris, corresponds to seismic U2. The bottom part of the core (from 125 to $355 \mathrm{~cm}$ ) is expressed by muds alternating with thin organic-rich horizons occurring at the core base. This facies is interpreted as seismic U1 (Fig. 10).

SRQ3-KS34 illustrates the sedimentary succession preserved in the Aulne estuary (-10 m of water depth). This core, located on the SRQ-80006 seismic line, is characterized by two different sedimentary facies (Fig. 2). The first 175 centimeters are constituted by silty sediment intercalated with maërl beds several centimeters thick. It rests on a shelly layer, interpreted as medium sand, 
starting with a concentrated section of debris shell. The first sedimentological facies is interpreted as U3 and the second, at the bottom, as U2.

\section{Discussion}

The purpose of this section is to examine the sequential stratigraphy of the deposits (1), to reconstruct the history of sedimentary infilling (2), to determine the control of each of the factors (sea-level rise, morphological inheritance, and hydrodynamic changes) on the deposition (3), and finally to explain the particularity of the bay as compared to other systems (4).

\subsection{Chronostratigraphic interpretation}

Based on the acoustic geometries (Figs. 4,5 and 6), core descriptions, and radiocarbon ages (Fig. 10) and including the sequential stratigraphic principles (Mitchum et al., 1977; Posamentier and Vail, 1988; Van Wagoner, 1988; Zaitlin et al., 1994; Myers and Milton, 1996; Posamentier, 2001; Catuneanu, 2006) a chronostratigraphic scheme has been proposed (Fig. 11)

The basal unit (U0) corresponds to the first stage of the sedimentary infill and, it is restricted to the paleo-valley floor, in the secondary network and it generally smooths the bedrock irregularities (Fig. 9). Although it was not recovered by coring, its chaotic geometry and discontinuous reflectors are interpreted as typical signature of heterogeneous and coarse continental deposits (gravels). Continental facies corresponds to preserved channel lag and are assumed to have been deposited during the last or previous sea-level lowstands. The unit $\mathrm{U} 0$ is thus interpreted as a lowstand system tract (LST). The LST is bounded to the base by the first sequence boundary (SB1) and to the top by the erosive unconformity D1 corresponding to a second sequence boundary (SB2) (Fig. 11) Jouet et al., 2003; Proust et al., 2010; Tessier et al., 2010). The SB2 surface also merged with the flooding surface (FS) marking the transition with the U1 unit. 
The U1 and U2 units form two parts of a transgressive system tract and constitute the main deposits of the Bay of Brest (TST1, TST2). The TST1 (U1) is better preserved in the shallowest part of the bay $(<10 \mathrm{~m})$ and on the medium terraces surrounding the estuarine axis of the Aulne and Elorn (Fig. 9).

The deposits, presenting cut-and-fill facies in the shallowest parts (mud with organic-rich horizons), constitutes the origin of the Corbeau bank and the infill of the embayment bordering the Aulne paleo-valley (Daoulas and Poulmic) (Figs. 6, 7 and 8). Similarly, the TST1 constitute the main part of the embayment infilling of the Roscanvel and Fret bays. This unit is also recognized on the paleo-valley rims in the central part of bay, especially in the convex part of the meanders (Figs. 5 and 8). Its deeper deposits ( $<30$ meters of water depth) could not be sampled due to sandy bodies preventing penetration of the gravity corer. Nevertheless, due to the geometry reflectors they can be interpreted as estuarine deposits corresponding to different settings. They are assumed to correspond to supratidal and intertidal flat deposits in shallow parts with preserved stacked tidal channels. In contrast, prograding and aggrading geometries, observed in the deeper part, suggest a relative high hydrodynamic regime allowing formation of sanddominated point bars and spit bars along subtidal sinuous channels as described by Ginsberg and Aliotta (2011). Despite the lack of radiocarbon dating, we assume that the unit development is correlated with the beginning of the marine flooding of the bay marked by an input of marine sands through the paleo-channel network.

TST1 and TST2 are separated by the D2 surface which shows a large extension through the Bay of Brest. This unconformity, highlighting the transition between intertidal and subtidal deposits, is interpreted as a tidal ravinement surface (TRS) (Fig.11) resulting from the landward migration of the maximum tidal energy zone (Swift, 1968; Dalrymple et al., 1992; Posamentier \& Allen, 1993; Cattaneo \& Steel, 2003 Tessier et al., 2012). The radiocarbon ages allow us to bound the D2 surface range between $7777 \pm 102$ and $7902 \pm 114$ cal. yr B.P. in the embayment foot slope. 
The TST 2 (U2) is largely widespread over the entire bay (Fig. 9). The corresponding radiocarbon ages suggest a late Holocene age (6801 \pm 141 to $3184 \pm 164$ cal yr B.P) (Fig. 10). The TST2 deposits are composed of a thin shelly marine sand cover associated with a silty matrix at the edge of embayments and channels and would correspond to subtidal deposits. On the top of tidal flats, the TST2 acts as an impermeable barrier preventing the upward migration of biogenic gas (Figs. 7 and 8). In the paleo-network it forms large sandy bedforms interpreted to be estuarine tidal banks (Fig. 6). Their structure suggests the deposit of a high-energy marine environment oriented in agreement with tidal current channelization. The internal reflectors prograde above U0 as observed in figure 8, or on the meander deposits formed by U1 (Figs. 5 and 8) or again over the channel levees (Fig. 7). Locally it also shows horizontal conformable deposits covering the underlying units of the paleo-channel bottom. The unit $\mathrm{U} 2$ is thus associated with a marine deposit environment of high-energy in the main paleo-network and low-energy on the top of embayments.

The D3 unconformity marks the transition between the present-day (U3) and the late holocene deposits (U2). Surrounded by ages ranging from $2025 \pm 129$ cal. yr B.P to $3184 \pm 164$ cal. yr. B.P, it may correspond to be the Maximum Flooding Surface (MFS) (Fig. 11).

Finally, the uppermost unit U3, marks the stabilization of the sea-level, and constitutes the highstand system tract (HST). It drapes the previous units as a thin shelly sand layer on the top of tidal banks organized in dunes or ripples (Fig. 9). More developed in the shallowest parts and estuarian approaches, it is constituted by silty-sand sediments interbedded with red algae bed layers. Common in Brittany due to its ecology (Grall and Hilly, 2002), the maërl algae can be interpreted as a solid marker of the stabilization of marine environment dated in cores at

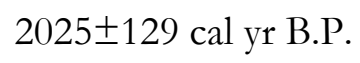

\subsection{The history of the Holocene infilling}


The sedimentary infilling of the Bay of Brest presents three different systems tracts organised into one sequence associated with the final stages of the last marine Holocene transgression (Figs. $13 \mathrm{~b}$ and 12). This sequence, highlighting the landward retreat of tidal processes from the last lowstand around $26000 \mathrm{cal} \mathrm{yr} \mathrm{B.P} \mathrm{(Peltier} \mathrm{and} \mathrm{Fairbanks,} \mathrm{2006)} \mathrm{to} \mathrm{present-day} \mathrm{highstand}$ conditions; it can be divided into four stages.

\section{A. From the last low sea-level to 10000 cal yr B.P}

During lowstand and glacial conditions, continental environments were dominant (Fig. 13b) and subjected to subaerial erosion. The basal infill of the paleo-fluvial system (LST) is attributed to last or oldest glacial deposits or/and periglacial "heads" which were installed in the secondary network (Figs. 5, 7, 8 and 9) but also in the gullies dug in rocks (Fig. 9). Previously observed in former studies, it was interpreted as fluvial buried deposits in the Bay of Brest (Baltzer et al., 2010) and in the paleo-valleys of Douarnenez (Jouet et al., 2003) and Vilaine (Menier et al., 2010; Traini et al., 2013). When this unit is preserved on terraces, it is often associated with periglacial heads (Babin et al., 1969, Morzadec-Kerfourne, 1974) (Fig. 12, -35 meters).

During the major phases of sea-level rise and at the end of the debated melt water pulse 1B (Bard et al., 2010), the sea gradually invaded the riverbed as observed in figure 12 (-35 meters).

According to the sea-level curve (at -35 meters, Fig. 13), around $10000 \mathrm{cal}$ yr BP (Camoin et al., 2012), the bay switched from a strictly continental domain to the first stage of a ria confined in the main network (Evans \& Prego, 2003). This environment at the fluvial-marine transition (Dalrymple \& Choi, 2007; Van den Berg et al., 2007) corresponds to a landward extension of the tidal influence that is always combined with the fluvial-flood processes. The meandering morphology of river rims generates an important segregation of the bidirectional tidal currents as observed in the present-day at the upstream comparable environments (Dalrymple et al., 1992; 
Brooks et al., 1999; Dalrymple et al., 2012). This induces the establishment of point bars and spit bars (U1, Fig. 9) in the convex part of the channel (Billeaud et al., 2007; Dalrymple and Choi, 2007; Van den Berg et al., 2007, Ginsberg and Aliotta, 2011; Jablonski and Dalrymple, 2016). The best examples of this in the Bay of Brest are found at the confluence of the Aulne river and its secondary network (Fig. 9). The unit geometry testifies to the migration of the meander toward the channel centre. This part constitutes the deeper early stage of the flooding of the bay, recorded by the first transgressive system tract (TST1).

\section{B. From 10000 to 7000 cal yr B.P}

During this period the sea-level continued to rise, the flooding of the bay progressed and submerged the topographic threshold separating the channel bottom (-35 meters) and the central plateau (-25/-20 meters). This suggests a brutal transgression (up to $10 \mathrm{~cm} / \mathrm{yr}$ ) of the sea as illustrated in figure 12 (-26 meters). Assuming that the tidal range is the same as the present-day (Goslin et al., 2015), the higher parts of the bay ( $<10$ meters) are still continental, the central terrace is subject to the tide, and the channel is strictly marine. The percentage of the area submitted to the tidal range increases drastically and the central terrace offers a large shallow area for sedimentation (Fig. 13b). As observed in the actual inner estuaries (Perillo, 1995; Dalrymple et al., 2012), the central channel is surrounded by salt marsh and tidal flats. However, there is no evidence for, or remnants of, the development of this tidal flat in the central terrace. Indeed, the sediment thickness in this central part barely reaches up to 1 meter and is mainly formed by the last unit (HST), meanwhile 5 to 10 meters of corresponding deposit are observable on the fluvial terraces surrounding the central paleo-network and also along the foot slopes of the Roscanvel and Fret bays (Fig. 9). Two hypotheses explain the absence of deposits on the central terrace: (1) sediments were eroded by tidal currents or (2) the terrace was by-passed by sedimentation and never buried. The combined effects of the rate of sea-level rise and the inherited substratum morphology, discussed in the next section (5.3), rather refute the second 
hypothesis. As the sea-level carried on rising, it caused the rapid backstepping of the intertidal area. As observed in figure 12 (-10 meters), the flooding finally reached the shallowest part of the bay and covered the second topographic threshold separating the central terrace (-25/-20 meters) from the embayments (-10 meters). As illustrated in figures 7,8 and 11, tidal flats associated with the TST1 extend from the bank deposits along the main channels to the embayments which present the cut-and-fill facies also observed in other estuaries (Dalrymple et al., 2012; Tessier et al., 2012). This took place during the early Holocene between 9000 and $7000 \mathrm{cal} \mathrm{yr} \mathrm{BP}$ when the sea-level rise was still rapid $(1 \mathrm{~cm} / \mathrm{yr})$ and graded from -30 to -10 meters for the deeper part and up to 5 meters for the shallowest parts (Camoin et al., 2012; Fig. 13). The flooding progressively spread throughout the whole bay. The establishment of aggrading tidal flats was stopped by a tidal ravinement surface around $7500 \mathrm{cal}$ yr B.P at the embayment foot slope, with strong tidal currents installation, and exhibited continuous growth in the shallow areas until $7000 \mathrm{cal}$ yr B.P

(Fig. 13). The ravinement eroded the sand-prone marine deposits and dispersed the eroded sediments towards the shallow sheltered part of the bay. At this time, the bay switched to the third infilling stage.

\section{From 6800 to 3000 cal yr B.P}

The rate of sea-level rise sharply decreased $(0.08 \mathrm{~cm} / \mathrm{yr})$ around $6500-6000 \mathrm{cal}$ yr B.P and reached -5 meters (Camoin et al., 2012; Goslin et al., 2015). As a consequence of the relative sealevel stabilization, the erosional ravinement surface characterizes the end of transgressive deposits (Cattaneo and Steel, 2003).Only the higher part of embayments is intertidal while the central terrace is converted to a subtidal regime (Fig.12). Tidal banks ( TST2) can be interpreted as a bar chain system, similar to those observed in the Bay of Fundy (Dalrymple et al., 1990; Dalrymple and Rhodes, 1995), grew in the channel axis (Fig. 9, U2). Their installation suggests the establishment of strong tidal currents and the installation of ebb- and flood-dominant channels that are characteristic to the mouths of tide-dominated estuaries (Dalrymple 
et al., 2012). On the contrary of the central part, the shallower parts were still submitted to the tidal range and the tidal flat continued to grow in low-energy conditions. This stage ended around $3000 \mathrm{cal}$ yr BP, when the sea-level is as high as the present-day (Goslin et al, 2015). The MFS marked a pause in the sedimentary depositions corresponding to a starvation in sediment-supply rate (Baum and Vail, 1988).

\section{From 2,000 to present-day}

The HST takes place when the entire bay is submerged by the sea. Intertidal areas have migrated landward in the coastal parts. The central basin is mainly marine dominated and the estuary mouth has migrated upstream of the Brest harbour for the Elorn River, and upstream of Longue island for the Aulne. The centre of the bay is subjected to strong tidal currents that prevent the deposition of fine sediment accumulated in the shallowest parts (Gregoire et al., 2016). After the MFS, tidal bars and muddy flat are preserved and oriented to the present-day circulation. Most of the deposits take place in the embayment and estuaries but also on the top of tidal banks where the sand-gravel shelly sediment is organized in dunes. The installation of maërl beds is observed in the embayments. The ecology of these red algae suggests low-energy, non-turbid salt water conditions (Grall and Hilly, 2002).

\subsection{Main factors controlling the infilling of the estuarine bay}

To explain the major stages of the sedimentary infill of the estuarine Bay of Brest, it is necessary to underline the importance of three main factors: (1) the amplitude and rate of the sea-level change, (2) the inherited morphology of substratum, and (3) the establishment of coastal hydrodynamism (tide, fluvial, and waves). As mentioned by Cattaneo and Steel (2003), the role of inherited morphology for transgressive deposits is mainly illustrated in terms of the ratio between the slope gradient of the inherited physiography and the rise in relative sea-level. This defines the speed of the landward shift of the shoreline and the possibility of deposition and preservation of 
sedimentary deposits above the transgressive surface. Such a phenomenon seems to occur across the Bay of Brest and it is worthwhile to examine this interaction in regards to the database available. First of all, the irregular physiography of the bay induced a contrasted distribution of coastal environments during the transgression and particularly the lateral extension of the intertidal areas. If the gradient of the substratum is uniform, the intertidal area records a uniform backstepping with a preserved extension. In contrast, an increase in the gradient will reduce its surface. In this way, if we consider a preserved amplitude of tides (mean range of $5 \mathrm{~m}$ ) during the final stage of the last deglaciation, the position of the shoreline referring to the gradient of the substratum will change the extension of the intertidal area within a range of $15 \%$, according its backsteps over a relatively flat surface or along a slope break (Figs. 12 and 13). These assumptions bring constraints for the evaluation of depositional environments and their more or less rapid evolutions during the Holocene flooding.

Moreover, the rise of the relative sea-level also varies and decreases since the last $10000 \mathrm{cal} \mathrm{yr}$ B.P. (Fig. 13d; Camoin et al.,2012; Goslin et al., 2015). As a consequence, the interaction of these two parameters (rise of sea-level and previous morphology) controls the shoreline retreat and the depositional regime. The shoreline migration was computed (Fig. 13c) for a representative morphologic section through the bay extending from the paleo-valley to the upper terrace (Fig. 13a). An additional virtual morphologic section showing a regular gradient was also considered for comparison. The curves are correlated with the timing of the system tracts succession and the preserved sedimentary rates estimated from core analyses. Results clearly show two peaks of shoreline retreat $(10$ and $6 \mathrm{~cm} / \mathrm{yr})$ occurring at about $8500 \mathrm{cal} \mathrm{yr} \mathrm{B.P.} \mathrm{and} 7000 \mathrm{cal} \mathrm{yr} \mathrm{B.P}$ separated by very low rates. Values significantly differ from rates of retreat computed for the virtual section showing quite a constant rate from 10000 to $6000 \mathrm{cal} \mathrm{yr} \mathrm{B.P.} \mathrm{before} \mathrm{subsequently}$ becoming very faint. The two peaks are synchronous with the flooding of the terraces at $-25 /-20$ meters and $-15 /-10$ meters. In the first case, the conjunction of the rapid sea-level retreat and accommodation allow the development of the first member of the transgressive system tract 
(TST1) with a preserved sediment mean rate of $0.27 \mathrm{~cm} \mathrm{yr}^{-1}$ and confined to the embayments and coves. On the lower terrace (T2, Fig. 3), the rapid transgression across the low-gradient topography is assumed to generate an erosional surface (TRS) and a dispersion of the sediments. Thus the absence of TST1 corresponding deposits above on the central plateau could be explained by this conjunction. The second peak is synchronous with the tidal ravinement surface recorded across the shallow parts of the bay. The decrease of accommodation and the fast shoreline retreat prevent any deposition and favour the erosion of previous deposits according to the landward migration of tidal hydrodynamics. Between 7000 and $3000 \mathrm{cal} \mathrm{yr} \mathrm{B.P.,} \mathrm{the} \mathrm{slow}$ retreat of the shoreline and the preservation of a modest accommodation allowed the development of TST2. Finally, the MFS (3000-2000 cal yr B.P.) marked the end of the transgressive deposits. As no major change is observed in shoreline retreat and accommodation during this time period, the starvation recorded between the TST2 and HST is mainly interpreted as a consequence of local hydrodynamic evolution. The flooding of the entire bay enhanced shoaling and embayed coastal morphology; this was enough to trigger a modification in the tidal circulation, which adopted a similar pattern to the present situation. The HST are also influenced by human activities (Fichaut, 1984; Fernane et al., 2014) which modified the fluvial supplies and the redistribution of fine particles, but also by recurrent storms (Van Vliet la Noë et al., 2014) and the slight increase of the sea-level due to global warming (Krasting et al., 2016).

To summarize, the lowstand system tract takes place in regards to the fluvial transport, the evolution of transgressive deposits are closely controlled by the interaction of inherited morphology and the rise of relative sea-level. The setting of highstand deposits is explained by hydrodynamic factors mainly subject to the tidal currents.

\subsection{Comparison with other tide-dominated estuary systems}

The comparison of the Bay of Brest with other studies along the Atlantic coast is significant as it shows numerous other tide-dominated systems including bays, estuaries, and rocky basements 
that developed over large and low subsiding continental shelves (Chaumillon et al., 2010). The Bay of Brest infilling is mainly Holocene in age and takes place on a rocky coast in a tidedominated semi-enclosed environment with low fluvial supplies (Fig. 11). The particularity of the site is the stepped geometry of the transgressive and highstand sedimentary deposits, wellpreserved in shallow environments and partly infilled in the paleo-network. Indeed, compared with other proximal systems (Jouet et al., 2003; Proust et al., 2010; Tessier et al., 2010; Tessier et al., 2012; Traini et al., 2013; Menier et al., 2016), the Bay of Brest has preserved a remarkable fluvial morphology maintained by strong tidal currents and low modern fluvial sedimentary inputs. Unlike, the other systems, the narrow entrance (Goulet) of the bay (1) induces a strong channelization and amplification of the tidal currents which preventing deposition along the channel axes and (2) limits significantly the action of waves on sediment transport. Nevertheless, the Bay of Brest is closest to the Vilaine estuary, assimilated as a ria (Menier et al., 2010). In both cases, transgressive deposits are well-developed and the MFS is late (around $3000 \mathrm{cal} \mathrm{yr} \mathrm{B.P.;}$ Traini et al., 2013). As suggested by Tessier (2012), this time gap could be linked to low sediment input that allowed a maximum retrograding bay line to occur before the transition in tidal hydrodynamics and the emplacement of prograding deposits.

Compared with Spanish rias (Garcia-Gil et al., 2005; Martínez-Carreño and García-Gil, 2013), although the morphology was similar, the higher fluvial sediment input and the narrowest shelf allow the establishment of thicker and earlier estuarine deposits. In the Bay of Brest, the low sedimentary supply prevents the development of highstand deposits as seen in large tidedominated estuaries in coastal China (Hori et al., 2001; Zhang et al., 2014). Thus, the sedimentary infilling of the Bay of Brest retraces the evolution of the system from a continental environment to a marine environment. The landward extension of the estuary environment is conserved thanks to the stepped domains with the development of the inner estuary deposits in the shallowest part and outer estuary deposits in the central part. In contrast with other systems where the younger system erodes the older (Green et al, 2013), in the Bay of Brest the estuarine 
bodies of the Holocene transgression seem to be preserved and maintained under the tidal current regime.

\section{Conclusion}

The infilling of the Bay of Brest is characterized by four seismic units which have been correlated with sedimentary facies and radiocarbon ages. The stratigraphic scheme shows several system tracks associated with the Holocene marine transgression, which progressed on the stepped substratum from the central paleo-network to the shallowest parts. The first system tract corresponds to a fluvial deposition in context of a sea-level lowstands(Pleistocene). The second is characterized by sediment deposited during the marine transgression. It is composed of a first deposition stage associated with an intertidal environment (between 9000 and 7000 cal yr B.P.) and a second stage (6800 and $3000 \mathrm{cal} \mathrm{yr} \mathrm{B.P.)} \mathrm{characterized} \mathrm{by} \mathrm{supratidal} \mathrm{deposits} \mathrm{associated}$ with the installation of tidal bars in the central part of the bay and the growth of tidal flats in the shallowest embayments. They are separated by an erosional surface interpreted as a tidal ravinement surface. The last system track extends from $2000 \mathrm{cal}$ yr B.P. to the present day and is lower bounded by the maximum flooding surface. It characterizes the modern sedimentation subjected according to the tidal currents and fluvial processes.

Three main factors controlled the deposition of sediment in such confined fluvial-estuarinemarine environments during the Holocene marine transgression: sea-level rise, bedrock morphology, and hydrodynamic conditions. The first stage of the transgressive tract is mainly controlled by the inherited morphology of the substratum, whereas the second stage is dominated by the installation of tidal currents in the bay. The paleo-valley in the bay of Brest as in the regional estuarine bays (ie bay of Vilaine), is commonly incised in a bedrock substratum. The topographic bedrock of the French Atlantic coast acts on the local hydrodynamics and indirectly plays a key-role on the conservation of sediment deposition Moreover the original stepped bedrock of the bay of Brest and the narrow entrance, allow unique preservation of each 
depositional environment of the inner estuary in the embayments and the outer estuary in the central part. As the paleo-valley was not fully filled during the last Holocene transgression, the present-day tidal currents are focused in the main axis and this configuration favours the conservation of the trangressive sediment bodies. Thanks to its morphological configuration, the Bay of Brest constitutes a unique case study that we can use to identify and isolate the successive influences of the main controlling factors in sediment deposition in the context of a tidedominated and sheltered estuary at an ocean-continent interface. Evaluation of the sediment exchanges between the confined area and the open sea sink will constitute a natural progression of this work to complete our knowledge on the influence of marine processes in such a particular sedimentary system.

\section{Acknowledgment}

This work was enabled thanks to a grant from the Laboratoire d'Excellence, LabexMer [ANR-10LABX-19-01] and the regional Council of Brittany. Additional funding support was obtained through the "CHRAAB" project and allows us to establish AMS datation ${ }^{14} \mathrm{C}$. The authors are grateful to the officers and crew of the R/V Thalia (IFREMER) for the coring survey in the Bay of Brest and of the Albert Lucas (CNRS/IUEM) and Haliotis (IFREMER) for the seismic data and also our GM (IFREMER) and LDO (IUEM) colleagues for their assistance in all of the surveys. We would like to thank Antoine Carlier and the Rebent network for the acoustic and sedimentological data provided. The authors are also grateful to the improvement of the English version by Katalin Kovacs (Services de Relecture Scientifique, astronogirl666@gmail.com). Finally we would like to thank the editor Edward Anthony and the anonymous reviewers for their constructive reviews and suggestions greatly helped to improve the manuscript.

\section{References}


Allard, J., Chaumillon, E., Bertin, X., Poirier, C., Ganthy, F., 2010. Sedimentary record of environmental changes and human interferences in a macrotidal bay for the last millenaries: the Marennes-Oléron Bay (SW France). Bulletin de la Societe Geologique de France 181(2), 151-169.

Auffret, G. A., 1983. Dynamique sédimentaire de la marge continentale celtique-Evolution Cénozoïque-Spécificité du Pleistocène supérieur et de l'Holocène. Université de Bordeaux I, Bordeaux, pp. 355.

Babin, C., Didier, J., Moign, A., Plusquellec, Y., 1969. Goulet et rade de Brest: essai de géologie sous-marine. Revue de géographie physique et de géologie dynamique 11, 1-31.

Ballèvre, M., Bosse, V., Ducassou, C., \& Pitra, P., 2009. Palaeozoic history of the Armorican Massif: models for the tectonic evolution of the suture zones. Comptes Rendus Geoscience 341(2), 174-201.

doi: $10.1016 /$ j.crte.2008.11.009

Ballèvre, M., Catalán, J. R. M., López-Carmona, A., Pitra, P., Abati, J., Fernández, R. D., ... Martínez, S. S., 2014. Correlation of the nappe stack in the Ibero-Armorican arc across the Bay of Biscay: a joint French-Spanish project. Geological Society, London, Special Publications 405(1), 77-113.

doi: $10.1144 /$ SP405.13

Baltzer, A., Boutin, R., Stepanian, A., 2010. Apport de la sismique marine très haute résolution à l'étude de la rade abri de Brest (France). Revue Parali 3, 1-14.

Bard, E., Hamelin, B., Delanghe-Sabatier, D., 2010. Deglacial meltwater pulse 1B and Younger Dryas sea levels revisited with boreholes at Tahiti.Science 327(5970), 1235-1237.

Bassoulet, P., 1979. Etude de la dynamique des sédiments en suspension dans l'estuaire de l'Aulne: Rade de Brest. Université de Bretagne occidentale, Brest, pp. 211.

Baum, G.R., P.R., Vail, 1988. Sequence stratigraphy concepts applied to Paleogene units, Gulf and Atlantic Tertiary basins, in: Wilgus, C.K., Hastings, B.S., St.C.Kendall, C.G., Posamentier, H.W., Ross, C.A., Van Wagoner, J.C. (Eds.), Sea-Level Changes: An Integrated Approach. Social Economic Palaeontology Mineralogy, Special Publication 42, pp. 124-154.

Billeaud, I., Tessier, B., Lesueur, P., Caline, B., 2007. Preservation potential of highstand coastal sedimentary bodies in a macrotidal basin: example from the Bay of Mont-Saint-Michel, NW France. Sedimentary Geology 202(4), 754-775.

Brooks, D. A., Baca, M. W., Lo, Y. T., 1999. Tidal circulation and residence time in a macrotidal estuary: Cobscook Bay, Maine. Estuarine, Coastal and Shelf Science 49(5), 647-665.

Camoin, G. F., Seard, C., Deschamps, P., Webster, J. M., Abbey, E., Braga, J. C., ... Yokoyama, Y., 2012. Reef response to sea-level and environmental changes during the last deglaciation: Integrated Ocean Drilling Program Expedition 310, Tahiti Sea Level. Geology 40(7), 643-646.

Cattaneo, A., Steel, R. J., 2003. Transgressive deposits: a review of their variability. Earth-Science Reviews 62(3), 187-228. 
Catuneanu, O., 2006. Principles of sequence stratigraphy. Elsevier.

Chaumillon, E., Tessier, B., Reynaud, J. Y., 2010. Stratigraphic records and variability of incised valleys and estuaries along French coasts. Bulletin de la Société géologique de France, 181(2), 7585.

Cressard A., Augris C., 1981. Les granulats siliceux et calcaires du littoral français. Bull. Liaison Lab. Ponts et Chaussées Spe., IV, 69-80.

Dalrymple, R. W., Knight, R., Zaitlin, B. A., Middleton, G. V., 1990. Dynamics and facies model of a macrotidal sand-bar complex, Cobequid Bay-Salmon River Estuary (Bay of Fundy).

Sedimentology 37(4), 577-612.

doi: 10.1111/j.1365-3091.1990.tb00624.x

Dalrymple, R. W., Zaitlin, B. A., Boyd, R., 1992. Estuarine facies models: conceptual basis and stratigraphic implications: perspective. Journal of Sedimentary Research 62(6), 1130-1146.

Retrieved from http://archives.datapages.com/data/sepm/journals/v59-

62/data/062/062006/1130.htm

Dalrymple, R. W., Rhodes, R. N., 1995. Estuarine dunes and bars. Geomorphology and sedimentology of estuaries $53,359-422$.

Dalrymple, R.W., 2006. Incised valleys in space and time: an introduction to the volume and an examination of the controls on valley formation and filling, in: Dalrymple R.W., Leckie D.A., Tillman R.W. (Eds.), Incised valleys in space and time. SEPM special publications 85. Society for Sedimentary Geology, Tulsa, pp. 5-12.

Dalrymple, R. W., Choi, K., 2007. Morphologic and facies trends through the fluvial-marine transition in tide-dominated depositional systems: a schematic framework for environmental and sequence-stratigraphic interpretation. Earth-Science Reviews 81(3), 135-174.

Dalrymple, R.W., 2010. Tidal depositional systems, in: James, N.P, Dalrymple, R.W. (Eds.), Facies Models 4: St John's. Geological Association of Canada, pp. 201-231.

Dalrymple, R. W., Mackay, D. A., Ichaso, A. A., Choi, K. S., 2012. Processes, morphodynamics, and facies of tide-dominated estuaries, in: Davis, R.A., Dalrymple, R.W., Robert, W. (Eds.), Principles of Tidal Sedimentology. Springer, Netherlands, pp. 79-107.

Evans, G., Prego, R., 2003. Rias, estuaries and incised valleys: is a ria an estuary?. Marine geology 196(3), 171-175.

Fichaut, B. (1984). Réactualisation de la sédimentologie de la rade de Brest. Université de Bretagne Occidentale, Brest, pp. 250.

Fernane, A., Gandouin, E., Penaud, A., Van Vliet-Lanoë, B., Goslin, J., Vidal, M., Delacourt, C., 2014. Coastal palaeoenvironmental record of the last 7 kyr BP in NW France: Sub-millennial climatic and anthropic Holocene signals. The Holocene 24(12), 85-97.

Fischer, H.B., 1976. Mixing and dispersion in estuaries. Annual Review Fluid Mechanics, 8, $107-$ 133. 
García-García, A., García-Gil, S.,Vilas, F., 2005. Quaternary evolution of the Ría de Vigo, Spain. Marine Geology 220(1), 153-179.

Garcia-Gil, S., Vilas, F., \& Garcia-Garcia, A., 2002. Shallow gas features in incised-valley fills (Ria de Vigo, NW Spain): a case study. Continental Shelf Research 22(16), 2303-2315.

Garreau, J., 1977. Remarques sur la tectonique post-hercynienne en Bretagne occidentale. Norois 94(1), 179-192.

Garreau, J., 1980. Structure et relief de la région de Brest. Norois 108(1), 541-548.

Retrieved from http://www.persee.fr/doc/noroi_0029-182x_1980_num_108_1_3925

Ginsberg, S. S., Aliotta, S., 2011. Sediment Transport Circulation Pattern through Mesotidal Channels System, in: Ginsberg, S.S. (Eds), Sediment Transport. Croatia, pp. 275-294.

Goslin, J., Van Vliet-Lanoë, B., Stéphan, P., Delacourt, C., Fernane, A., Gandouin, E., ... Suanez, S., 2013. Holocene relative sea-level changes in western Brittany (France) between 7600 and 4000 cal. BP: Reconstitution from basal-peat deposits. Géomorphologie (4), 425-444.

Goslin, J., Lanoë, B. V. V., Spada, G., Bradley, S., Tarasov, L., Neill, S., Suanez, S., 2015. A new Holocene relative sea-level curve for western Brittany (France): Insights on isostatic dynamics along the Atlantic coasts of north-western Europe. Quaternary Science Reviews 129, 341-365.

Grall, J., Hily, C., 2002. Evaluation de la santé des bancs de maerl de la pointe de Bretagne (Rapport Direction Régional des Espaces Naturels de Bretagne). DIREN.

Green, A. N., Dladla, N., Garlick, G. L., 2013. Spatial and temporal variations in incised valley systems from the Durban continental shelf, KwaZulu-Natal, South Africa. Marine Geology 335, $148-161$.

Gregoire, G., Ehrhold, A., Le Roy, P., Jouet, G., Garlan, T., 2016. Modern morphosedimentological patterns in a tide-dominated estuary system: the Bay of Brest (west Britanny, France). Journal of Maps, 1-8.

Hallégouët, B., 1994. Formation de la rade de Brest, in : Corlaix, J.P. (Eds), Atlas permanent du littoral. Editmar, France, pp. 22.

Hinschberger, F., Saint-Réquier, A., 1970. Les sédiments vaseux au large du Finistère. Norois 67(1), 401-403.

Hori, K., Saito, Y., Zhao, Q., Cheng, X., Wang, P., Sato, Y., \& Li, C., 2001. Sedimentary facies and Holocene progradation rates of the Changjiang (Yangtze) delta, China. Geomorphology 41(2), 233-248.

Jablonski, B. V., Dalrymple, R. W., 2016. Recognition of strong seasonality and climatic cyclicity in an ancient, fluvially dominated, tidally influenced point bar: Middle McMurray Formation, Lower Steepbank River, north-eastern Alberta, Canada. Sedimentology. 
Jouet, G., Augris, C., Hallegouët, B., Le Roy, P., Rolet, J., 2003. La vallee d'Ys: un paleoreseau hydrographique immerge en baie de Douarnenez (Finistere, France). Comptes Rendus

Geoscience 335(5), 487-494.

Krasting, J.P., Dunne J.P., Stouffer, R.J., Hallberg, R.W., 2016. Enhanced Atlantic sea-level rise relative to the Pacific under high carbon emission rates. Nature Geosciences 9, 210-214.

doi: $10.1038 /$ ngeo 2641

Lericolais, G., Berné, S., Féniès, H., 2001. Seaward pinching out and internal stratigraphy of the Gironde incised valley on the shelf (Bay of Biscay). Marine Geology 175(1), 183-197.

Le Gall, B., Authemayou, C., Ehrhold, A., Paquette, J.L., Bussien D., Chazot, G., Aouizerat, A., Pastol, Y. 2014. LiDAR offshore structural mapping and U/Pb zircon/monazite dating of Variscan strain in the Leon metamorphic domain, NW Brittany. Tectonophysics, 630, 236-250

Martínez-Carreño, N., García-Gil, S., 2013. The Holocene gas system of the Ría de Vigo (NW Spain): Factors controlling the location of gas accumulations, seeps and pockmarks. Marine Geology 344, 82-100.

Menier, D., Tessier, B., Proust, J. N., Baltzer, A., Sorrel, P., Traini, C., 2010. The Holocene transgression as recorded by incised-valley infilling in a rocky coast context with low sediment supply (southern Brittany, western France). Bulletin de la Société Géologique de France 181(2), 115-128.

Menier, D., Estournès, G., Mathew, M. J., Ramkumar, M., Briend, C., Siddiqui, N., ... Labeyrie, L., 2016. Relict geomorphological and structural control on the coastal sediment partitioning, North of Bay of Biscay. Zeitschrift für Geomorphologie 60(1), 67-74.

Mitchum Jr, R. M., Vail, P. R., Sangree, J. B., 1977. Seismic stratigraphy and global changes of sea level: Part 6. Stratigraphic interpretation of seismic reflection patterns in depositional sequences: Section 2. Application of seismic reflection configuration to stratigraphic interpretation. 117-133.

Morzadec-Kerfourn, M. T., 1974. Variations de la ligne de rivage armoricaine au Quaternaire: analyses polliniques de dépôts organiques littoraux. Mémoires société géologique mineralogique de Bretagne 17, pp. 208.

Myers, K.J., Milton, N.J., 1996. Concepts and principles of Sequence stratigraphy, in: Emery, D., Myers, K. J. (Eds.), Sequence Stratigraphy. Blackwell Science, London, pp. 11-41.

Peltier, W. R., Fairbanks, R. G., 2006. Global glacial ice volume and Last Glacial Maximum duration from an extended Barbados sea level record. Quaternary Science Reviews 25(23), 33223337.

Perillo, G. M., 1995. Geomorphology and sedimentology of estuaries (Vol. 53). Elsevier, Hamsterdam.

Pommepuy M., 1977. SAUM de la rade de Brest. Etude courantologique. Rapport préliminaire, pp.18.

Retrieved from: http://archimer.ifremer.fr/doc/00055/16578 
Posamentier, H. W., Vail, P. R., 1988. Eustatic control on clastic sedimentation II-sequence and systems tract models, in: Sea Level Changes: An Integrated Approach. Wilgus, C.K., Hastings, B.S., Ross, C.A., Posamentier, H.W., Van Wagoner, J., St. C. Kendall, C.G. (Eds.), Society of Economic Paleontologists and Mineralogists Special Publication 42, pp. 125-154.

Posamentier, H. W., Allen, G. P., 1993. Variability of the sequence stratigraphic model: effects of local basin factors. Sedimentary geology 86(1), 91-109.

Posamentier, H. W., 2001. Lowstand alluvial bypass systems: incised vs. unincised. AAPG bulletin 85(10), 1771-1793.

Pritchard, D. W., 1955. Estuarine circulation patterns. Proceeding of the American Society of Civil Engineers, 717-727.

Proust, J. N., Renault, M., Guennoc, P., Thinon, I., 2010. Sedimentary architecture of the Loire River drowned valleys of the French Atlantic shelf. Bulletin de la Société géologique de France 181(2), 129-149.

Reimer, P. J., Bard, E., Bayliss, A., Beck, J. W., Blackwell, P. G., Ramsey, C. B., ... Grootes, P. M., 2013. IntCal13 and Marine13 radiocarbon age calibration curves $0-50,000$ years cal

BP. Radiocarbon 55(4), 1869-1887.

Ryan A. D., Heap A. D., Radke, L., and Heggie, D.T, 2003. Conceptural models of Australia's estuaries and coastal waterways: Applications for coastal resource management. Geoscience Australia, Record 2003/09, pp. 136.

Sorrel, P., Tessier, B., Demory, F., Baltzer, A., Bouaouina, F., Proust, J. N., ... Traini, C., 2010. Sedimentary archives of the French Atlantic coast (inner Bay of Vilaine, south Brittany): Depositional history and late Holocene climatic and environmental signals. Continental Shelf Research 30(10), 1250-1266.

Stéphan, P., Suanez, S., Fichaut, B., 2010. Franchissement et migration des cordons de galets par rollover. Impact de la tempête du 10 mars 2008 dans l'évolution récente du Sillon de Talbert (Côtes-d'Armor, Bretagne). Norois, Environnement, aménagement, société, (215), 59-75.

Stéphan, P., Goslin, J., Pailler, Y., Manceau, R., Suanez, S., Vliet-Lanoë, V., ... Delacourt, C., 2015. Holocene salt-marsh sedimentary infilling and relative sea-level changes in West Brittany (France) using foraminifera-based transfer functions. Boreas 44(1), 153-177.

Stuiver, M., and Reimer, P.J., 1993, Radiocarbon, 35, 215-230..

Retrieved from: http://calib.qub.ac.uk/calib/

Swift, D.J.P., 1968. Coastal erosion and transgressive stratigraphy. The Journal of Geology, 444456.

Tessier, B., Billeaud, I., Lesueur, P. , 2010. Stratigraphic organisation of a composite macrotidal wedge: the Holocene sedimentary infilling of the Mont-Saint-Michel Bay (NW France). Bulletin de la Societe Geologique de France 181(2), 99-113.

Tessier, B., Billeaud, I., Sorrel, P., Delsinne, N., Lesueur, P., 2012. Infilling stratigraphy of macrotidal tide-dominated estuaries. Controlling mechanisms: Sea-level fluctuations, bedrock morphology, sediment supply and climate changes (The examples of the Seine estuary and the Mont-Saint-Michel Bay, English Channel, NW France). Sedimentary Geology 279, 62-73. 
Tisnérat-Laborde, N., Paterne, M., Métivier, B., Arnold, M., Yiou, P., Blamart, D., Raynaud, S., 2010. Variability of the northeast Atlantic sea surface $\Delta 14 \mathrm{C}$ and marine reservoir age and the North Atlantic Oscillation (NAO). Quaternary Science Reviews 29(19), 2633-2646.

Traini, C., Menier, D., Proust, J. N., Sorrel, P., 2013. Transgressive systems tract of a ria-type estuary: The Late Holocene Vilaine River drowned valley (France). Marine Geology 337, 140-155.

Van den Berg, J. H., Boersma, J. R., Gelder, A. V., 2007. Diagnostics sedimentary structures of the fluvial-tidal transition zone - Evidence from deposits of the Rhine and Meuse, Netherlands Journal of Geosciences 86(3), 287-306.

Vail, P.R., Mitchum R.M.J., Todd, R.G., Widmer, J.M., Thompson S.I., Sangree, J.B., Bubb, J.N., Hatlelid, W.G., 1977. Seismic stratigraphy and global changes of sea level, in : Payton, C.E.

(Eds.), Seismic stratigraphy - Applications to Hydrocarbon Exploration : American Association of Petrolum Geologists Memoirs, pp. 49-212.

Van Vliet-Lanoë, B., Penaud, A., Hénaff, A., Delacourt, C., Fernane, A., Goslin, J., ... Le Cornec, E., 2014. Middle-to late-Holocene storminess in Brittany (NW France): Part II-The chronology of events and climate forcing. The Holocene 24(4), 434-453.

Van Wagoner, J. C.,1988. An overview of the fundamentals of sequence stratigraphy and key definitions. SEPM Special Publication 42, pp. 39-45.

Zaitlin, B. A., Dalrymple R.W., Boyd R., 1994. The stratigraphic organization of incised-valley systems associated with relative sea-level change, in: Dalrymple, R.W., Boyd, R., Zaitlin, B.A. (Eds.), Incised-valley systems: Origin and sedimentary sequences. Social Economic Paleontology Miner, Special Publication (51), pp. 45-60.

Zhang, X., Lin, C. M., Dalrymple, R. W., Gao, S., Li, Y. L., 2014. Facies architecture and depositional model of a macrotidal incised-valley succession (Qiantang River estuary, eastern China), and differences from other macrotidal systems. Geological Society of America Bulletin 126(3-4), 499-522.

\section{Figure caption}

Figure 1: Location map, bathymetric map and geologic map of the bay of Brest and the Iroise Sea.

Figure 2: (a) Location map of all seismic profiles used in this study. (b) Simplified bathymetric map showing the position of seismic lines and gravity-cores selected for this present paper. Bathymetric lines indicate the seabed depth spaced every 5 meters. The very clear grey parts indicate the shallowest parts comprises between 0 and -5 meters.

Figure 3: Morphology of the Paleozoic bedrock of the bay of Brest and its entrance. Some parts could not be represented due to the occurrence of the acoustic mask.

Figure 4: Characteristics and location of the different seismic units and facies encountered on chirp and sparker profiles.

Figure 5: Seismic line shot in the Aulne estuary and its interpretation (Geobrest11_18). The vertical scale is in two way travel time (ms TWT'T) for the seismic line and in meters for the interpretation. Horizontal scale given in meters. 
Figure 6: Seismic line shot in the Elorn estuary and its interpretation. The seismic profile is divided in a sparker line on the left (SMDS-22) and chirp line on the right (SRQ1-70012). The vertical scale given in two way travel time (ms TWTT) for the seismic line and in meters for the interpretation. Horizontal scale given in meters.

Figure 7: Fence diagram of seismic profiles showing the internal architecture of the Elorn estuary (see figure 2 for location). Dashed lines were used where the acoustics masks can hide the reflectors architecture. The collected cores are positioned along the seismic profile (see figure 11 for detailed description).

Figure 8: Fence diagram of seismic profiles showing the internal architecture of the main Aulne axis and its secondary network (see figure 2 for location). Dashed lines delimitate the acoustics

masks which hide the reflectors architecture. The core collected along the line is positioned (red) on the seismic profile (see figure 11 for detailed description).

Figures 9: Thickness of the sedimentary infill of the bay of Brest and its entrance in meters. Below the thickness of each unit (U0 to $\mathrm{U} 3$ ) has been represented. The dashed line represents the paleo-network.

Figure 10: Lithological description of selected gravity-cores for this study (see figure 2 for location). Radiocarbon calibrate ages are indicated on the right side of each log. The correspondence with seismic unit is given with colour bars on the left side.

Figure 11: Stratigraphic scheme of the sedimentary infilling in the bay of Brest. Figure shows the sedimentary deposition for each domain: embayments, central plateau, paleo-valley and estuarine rim. The thicknesses of LST (Low system tract), the TST (Transgressive system tract) and the HST (High system tract) fluctuate according to depositional environment. However the TST forms the main infilling of the bay and it is divided in two parts. The TST1 correspond to the lower part of the TST and it is separated from the upper TST (TST2) by a tidal ravinement surface (TRS) dated around 8000 and $7000 \mathrm{cal}$. yrs B.P. The HST and TST are separated by the Maximum Flooding Surface around 3000 and 2000 cal. yrs B.P.

Figure 12: Distribution diagram of the depths in the bay of Brest. The grey bars indicate the distribution of the present-day depths whereas the dashed bars the distribution of rocky basement without deposits. It is added the distribution of areas in percentage. The blue part represents the evolution of marine area according to the sea-level rise; the yellow represents the intertidal area and the brow part the continental domain. The intertidal area evolves according to the depths repartition.

Figure 13: (a) Rocky basement profile of the bay of Brest from the coast to the paleo-valley (blue) and virtual profile (red). The virtual profile was created from a line joining the depths 0 and 45 meters, the same as observable in the real profile. Slope gradients are indicate in black on the profile blue.(b) Steps of the sea level transgression in the bay of Brest, reconstructed from the seismic interpretation. The different seismic units have been added with the evolution of the sea level rising. The supratidal area is represented in brown and beige, intertidal area in green and subtidal area in blue. The tidal range used is similar as is present-day $(5 \mathrm{~m})$. The full line marks the limit between area.(c) Horizontal shoreline migration according to the theoretical profile (red) 
and substratum profile (blue). The rate of sea-level rise, according to the sea-level curve (in c) is characterized by the purple line (c) Sea-level curve according to Goslin et al. (2015) from 8 to 0 kyrs and Camoin et al. (2012) from 14 to 8 kyrs. (d) The sedimentation rate calculated from the radiocarbon age in the cores presented in this study according to the age. The sedimentation rates are correlated with the system tract (TST1, TST2 and HST) and non-deposit events (TRS and MFS).

\section{Table caption}

Table 1: Table summarising ${ }^{14} \mathrm{C}$ radiocarbon dating used for this study, their correction according to the age reservoir and their calibration. 

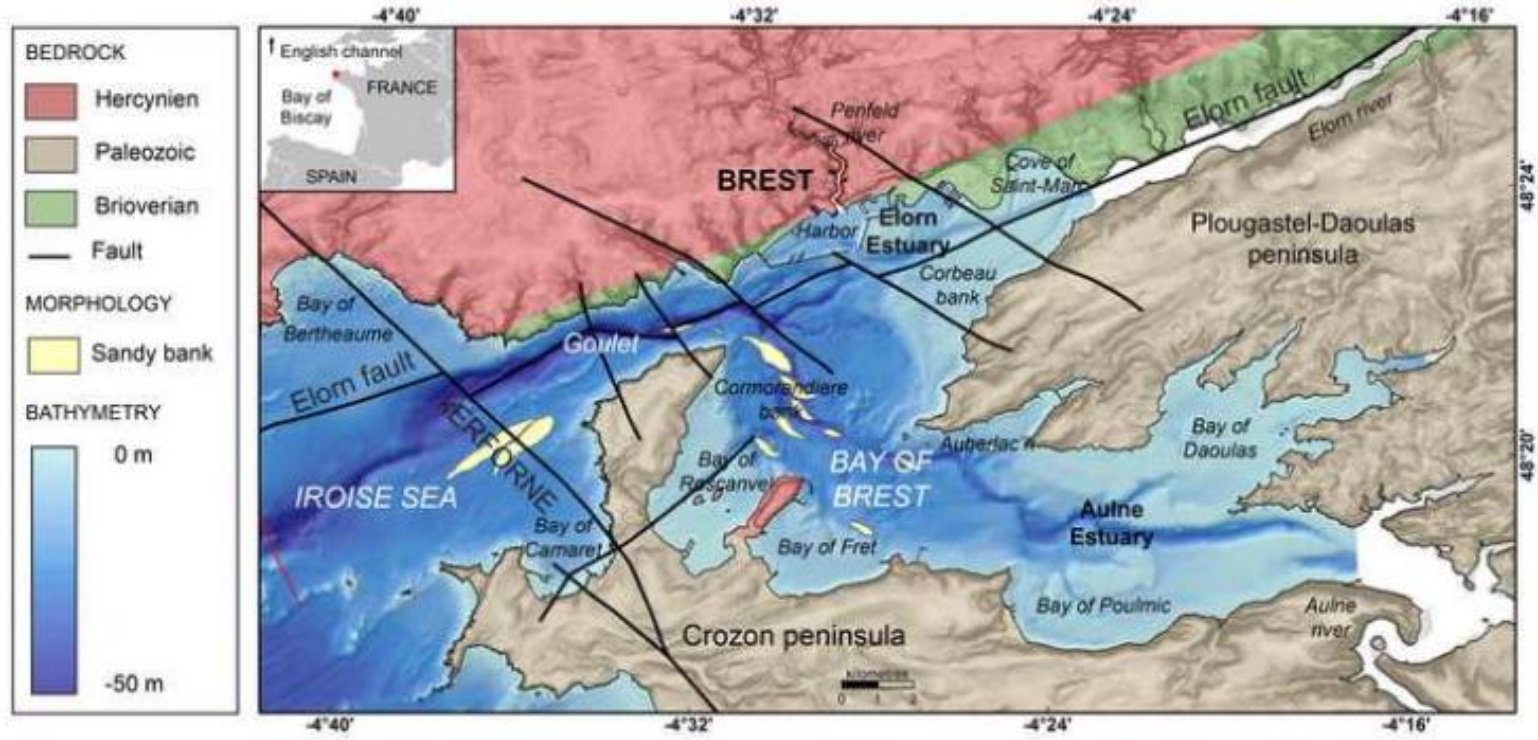

Figure 1 


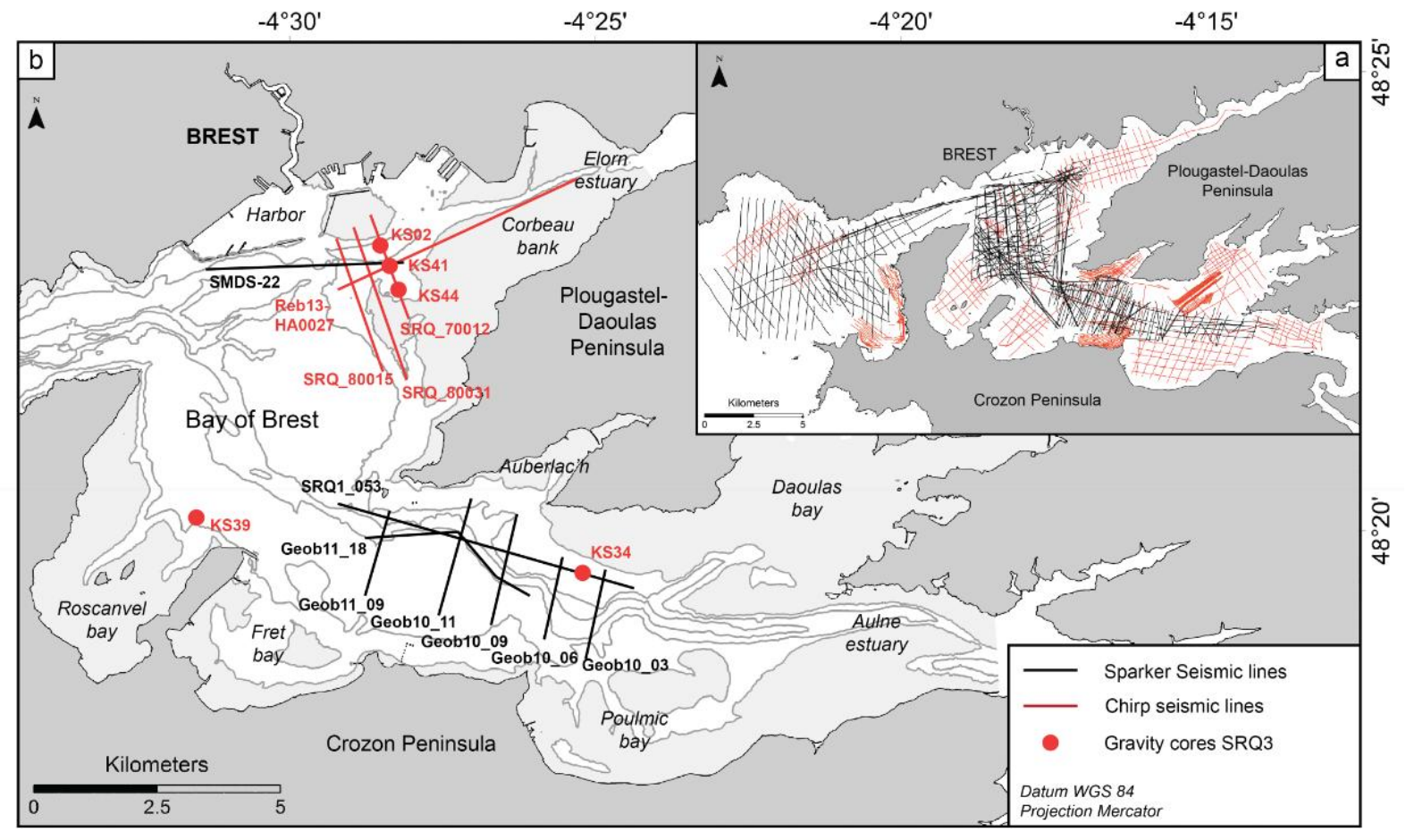

Figure 2 


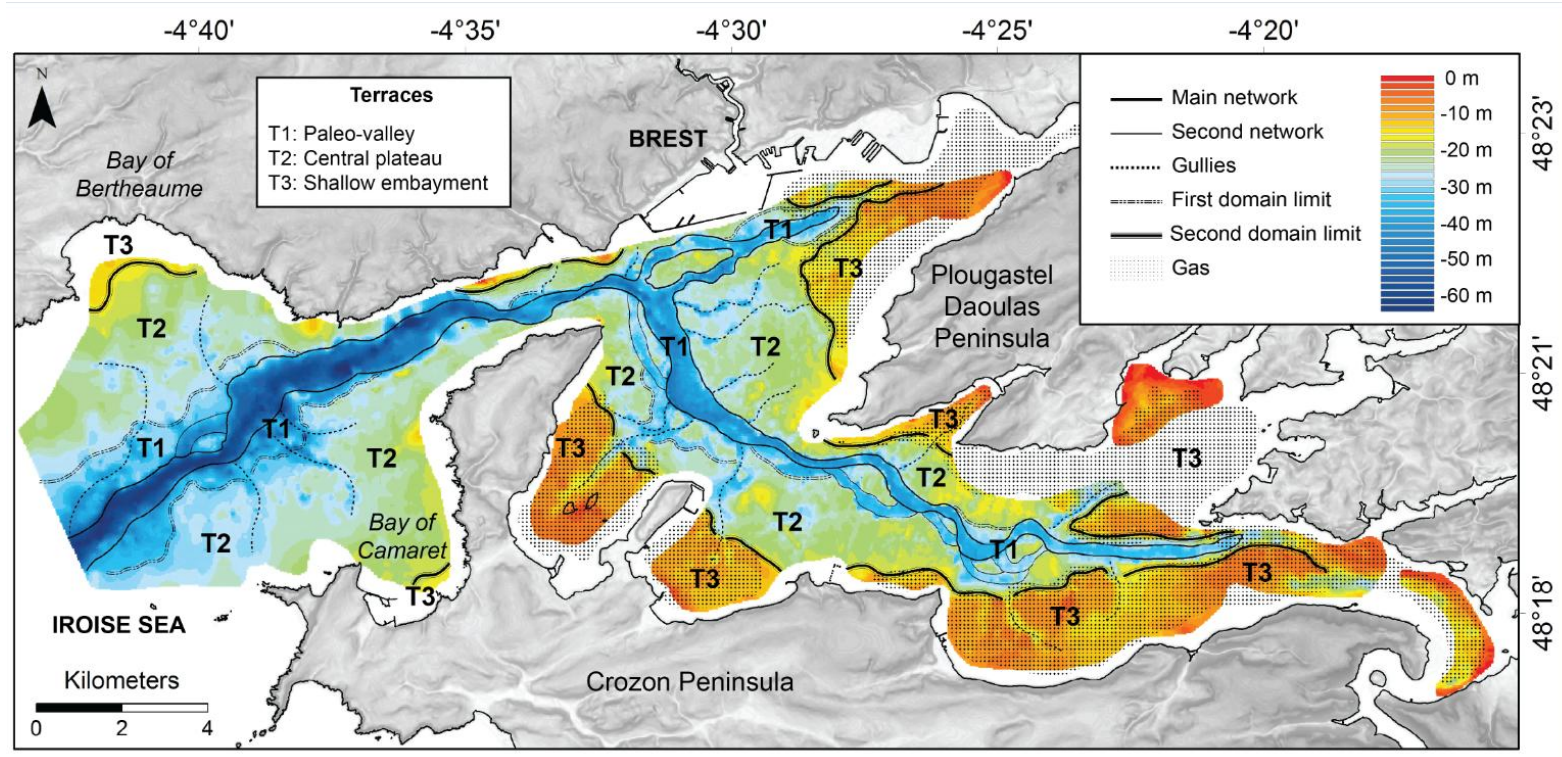

Figure 3 


\begin{tabular}{|c|c|c|c|c|c|c|c|c|c|}
\hline \multicolumn{2}{|c|}{ Seismic } & \multicolumn{2}{|c|}{ Illustration } & \multicolumn{3}{|c|}{ Acoustic facies } & \multirow{2}{*}{ Internal configuration } & \multirow{2}{*}{ Location } & \multirow{2}{*}{$\begin{array}{c}\text { Figure } \\
\text { illustration }\end{array}$} \\
\hline Unit & Facies & Sparker & Chirp & Frequency & Amplitude & Continuity & & & \\
\hline U3 & F3 & & & Low & Low & Medium & Aggradant parallel & $\begin{array}{l}\text { Widespread over } \\
\text { the previous infill }\end{array}$ & $\begin{array}{c}\text { Figure } \\
5,6,7,8,9\end{array}$ \\
\hline \multirow{6}{*}{ U2 } & F2p4 & & & High & Medium & Medium & Progradant oblique & Paleo-valley & $\begin{array}{l}\text { Figure } \\
8\end{array}$ \\
\hline & $F 2 p 3$ & & & Medium & High & High & Sigmoid progadant parallel & $\begin{array}{l}\text { Estuarine bars } \\
\text { and paleo-valley }\end{array}$ & $\begin{array}{c}\text { Figure } \\
7\end{array}$ \\
\hline & F2p2 & & & Medium & High & High & Aggradant parallel & $\begin{array}{l}\text { Estuarine bars } \\
\text { and paleo-valley }\end{array}$ & $\begin{array}{l}\text { Figure } \\
6,7,8,9\end{array}$ \\
\hline & F2p1 & & & Medium & High & High & Progradant oblique & $\begin{array}{l}\text { Estuarine bars } \\
\text { and paleo-valley }\end{array}$ & $\begin{array}{c}\text { Figure } \\
7,9\end{array}$ \\
\hline & $\mathrm{F} 2 \mathrm{e} 2$ & & & $\begin{array}{l}\text { Medium } \\
\text { to High }\end{array}$ & Medium & Medium & Aggradant parallel & Embayment & $\begin{array}{c}\text { Figure } \\
5,8,9\end{array}$ \\
\hline & F2e1 & & & Medium & High & Medium & Progradant parallel & $\begin{array}{l}\text { Embayment and } \\
\text { estuarine rims }\end{array}$ & $\begin{array}{c}\text { Figure } \\
7,8,9\end{array}$ \\
\hline \multirow{4}{*}{ U1 } & F1p3 & & & $\begin{array}{l}\text { Medium } \\
\text { to High }\end{array}$ & High & High & Aggradant parallel & Paleo-valley & $\begin{array}{l}\text { Figure } \\
8\end{array}$ \\
\hline & F1p2 & & & Very low & Very low & Very low & Chaotic & Paleo-valley & $\begin{array}{c}\text { Figure } \\
7\end{array}$ \\
\hline & F1p1 & & & High & High & High & Progradant oblique & $\begin{array}{l}\text { Incised-valley } \\
\text { rims }\end{array}$ & $\begin{array}{c}\text { Figure } \\
6,9\end{array}$ \\
\hline & F1e & & & Medium & High & High & Aggradant parallel & $\begin{array}{l}\text { Embayment and } \\
\text { estuarine rims }\end{array}$ & $\begin{array}{l}\text { Figure } \\
5,7,8,9\end{array}$ \\
\hline Uo & Fo & & & $\begin{array}{l}\text { Medium } \\
\text { to High }\end{array}$ & High & Low & Chaotic to sub-parallel & $\begin{array}{l}\text { Terraces and } \\
\text { paleo-valley }\end{array}$ & $\begin{array}{l}\text { Figure } \\
6,7,8,9\end{array}$ \\
\hline$A B$ & FAB & & & & & Very low & Chaotic & Bedrock & $\begin{array}{c}\text { Figure } \\
5,6,7,8,9\end{array}$ \\
\hline Gas & Fgas & & 8 & & & Very low & Chaotic & $\begin{array}{c}\text { Widespread } \\
\text { in embayment } \\
\text { and estuaries }\end{array}$ & $\begin{array}{l}\text { Figure } \\
5,7,8,9\end{array}$ \\
\hline
\end{tabular}

Figure 4 


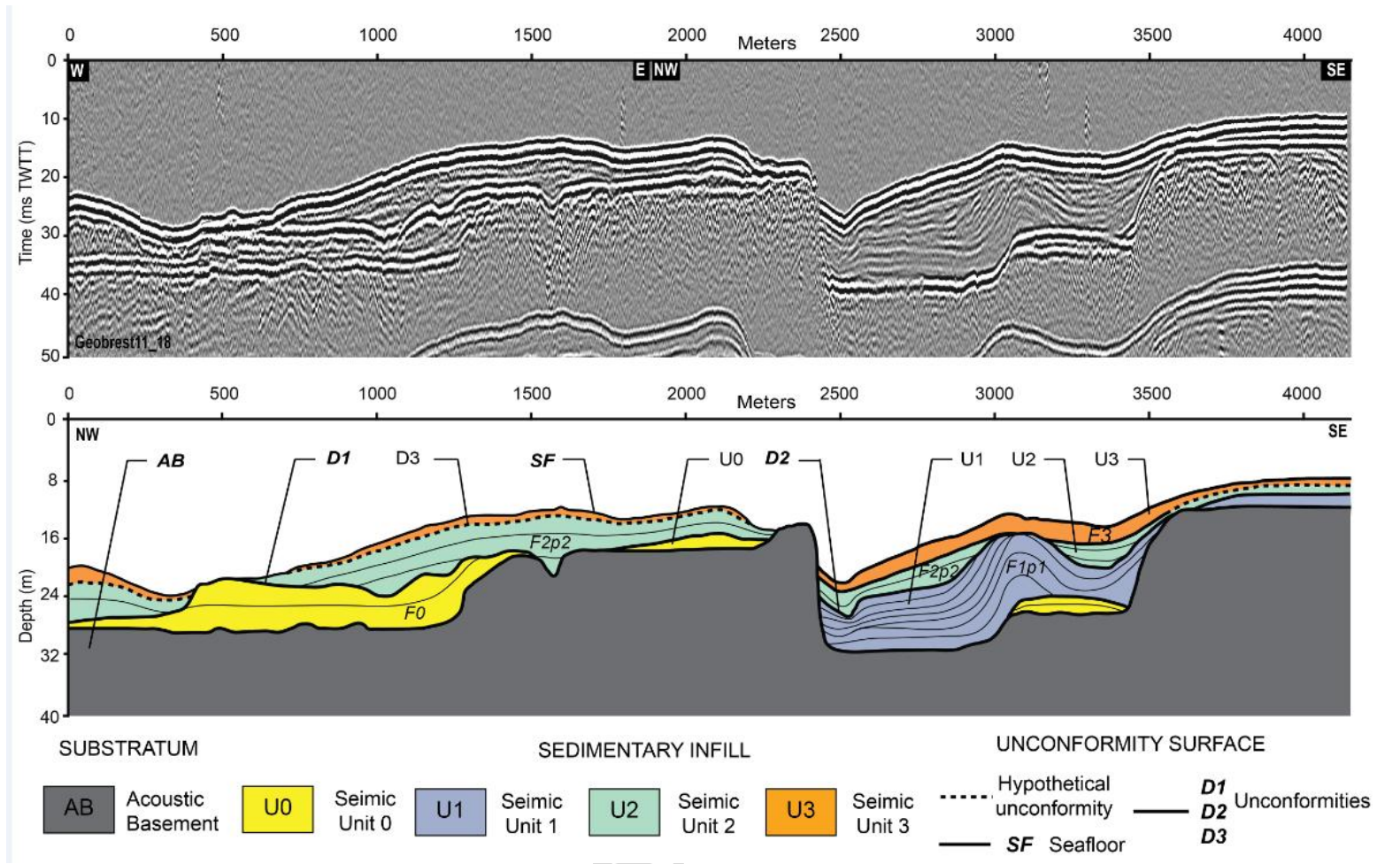

Figure 5 

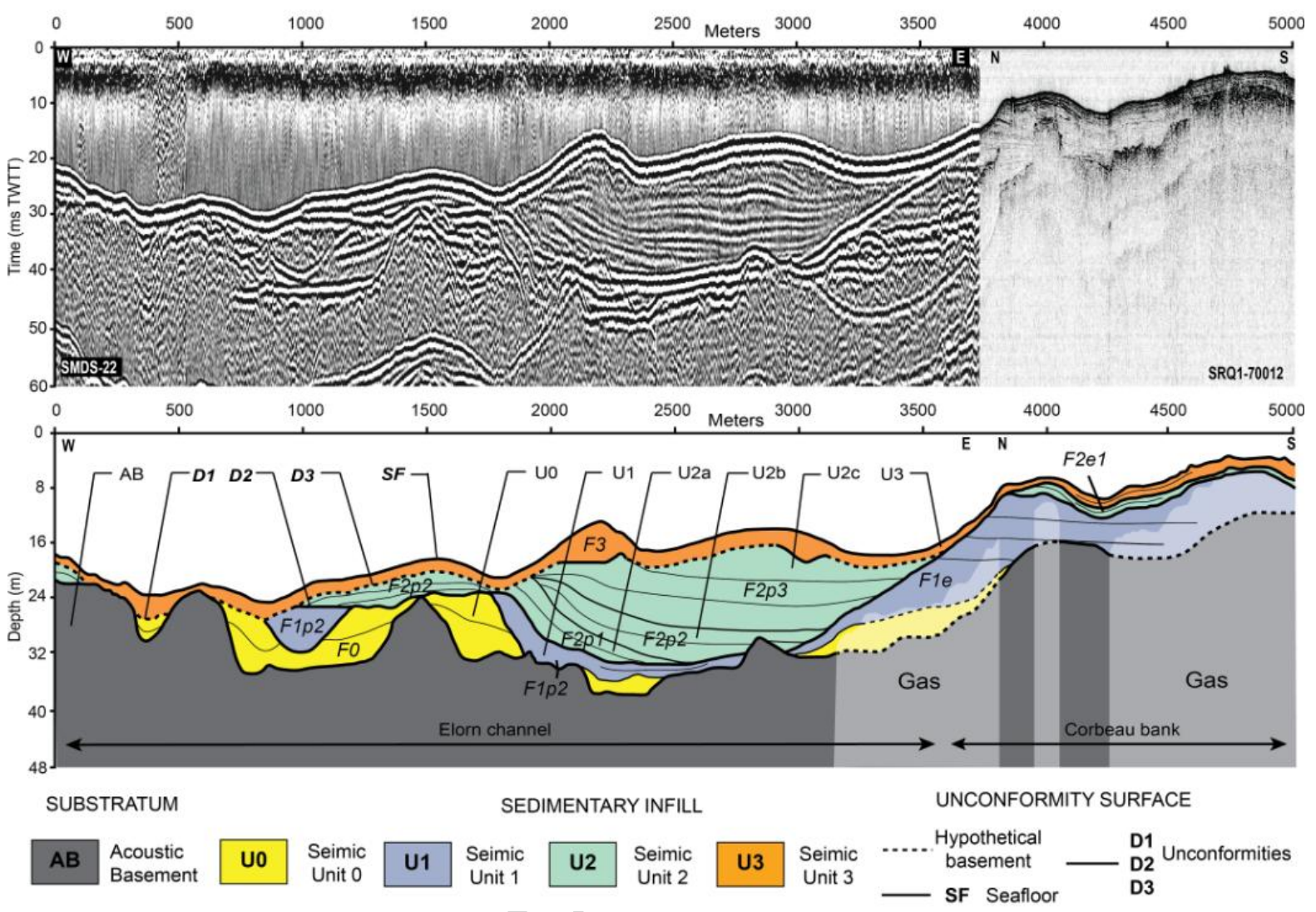

Figure 6 


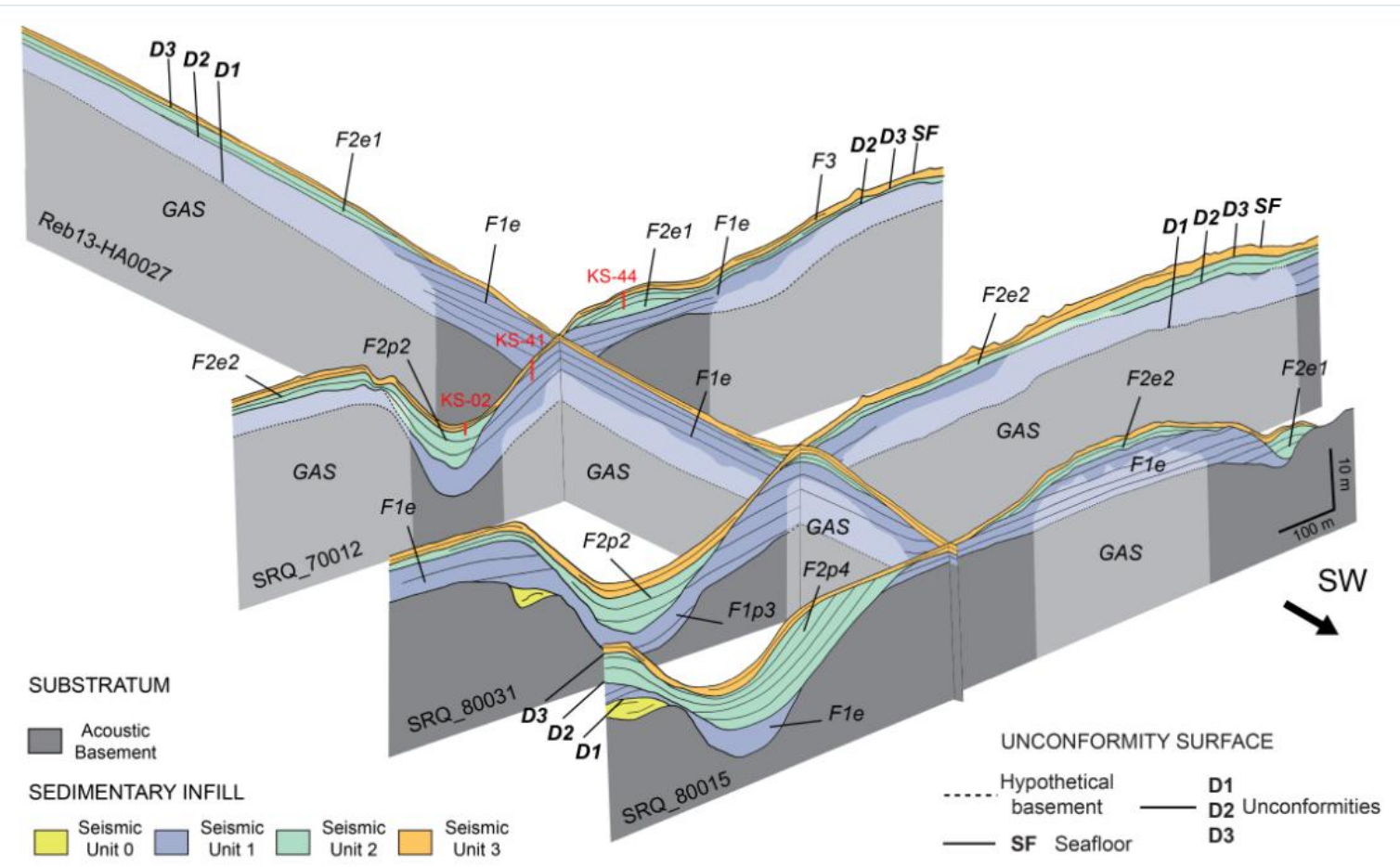

Figure 7 


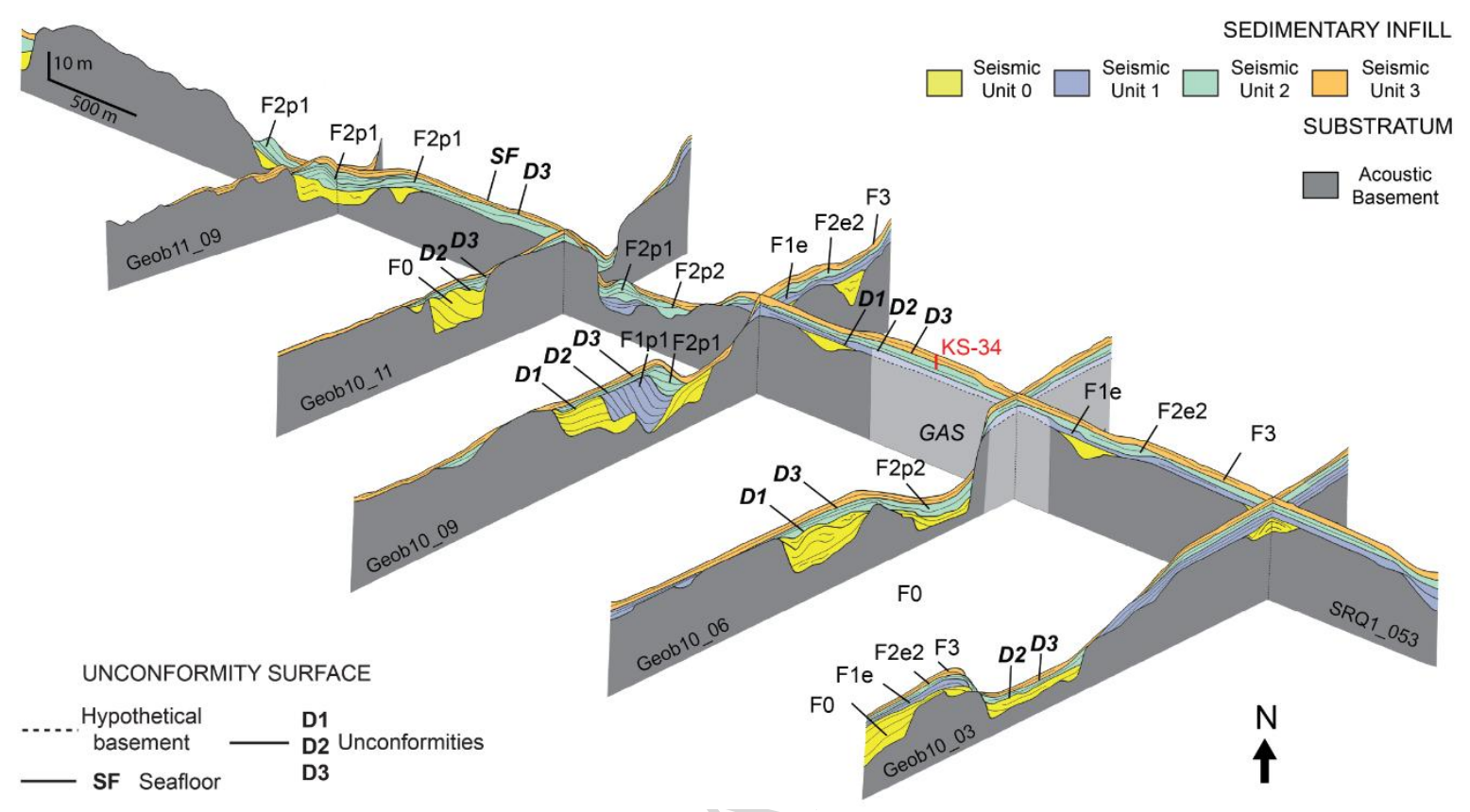

Figure 8 

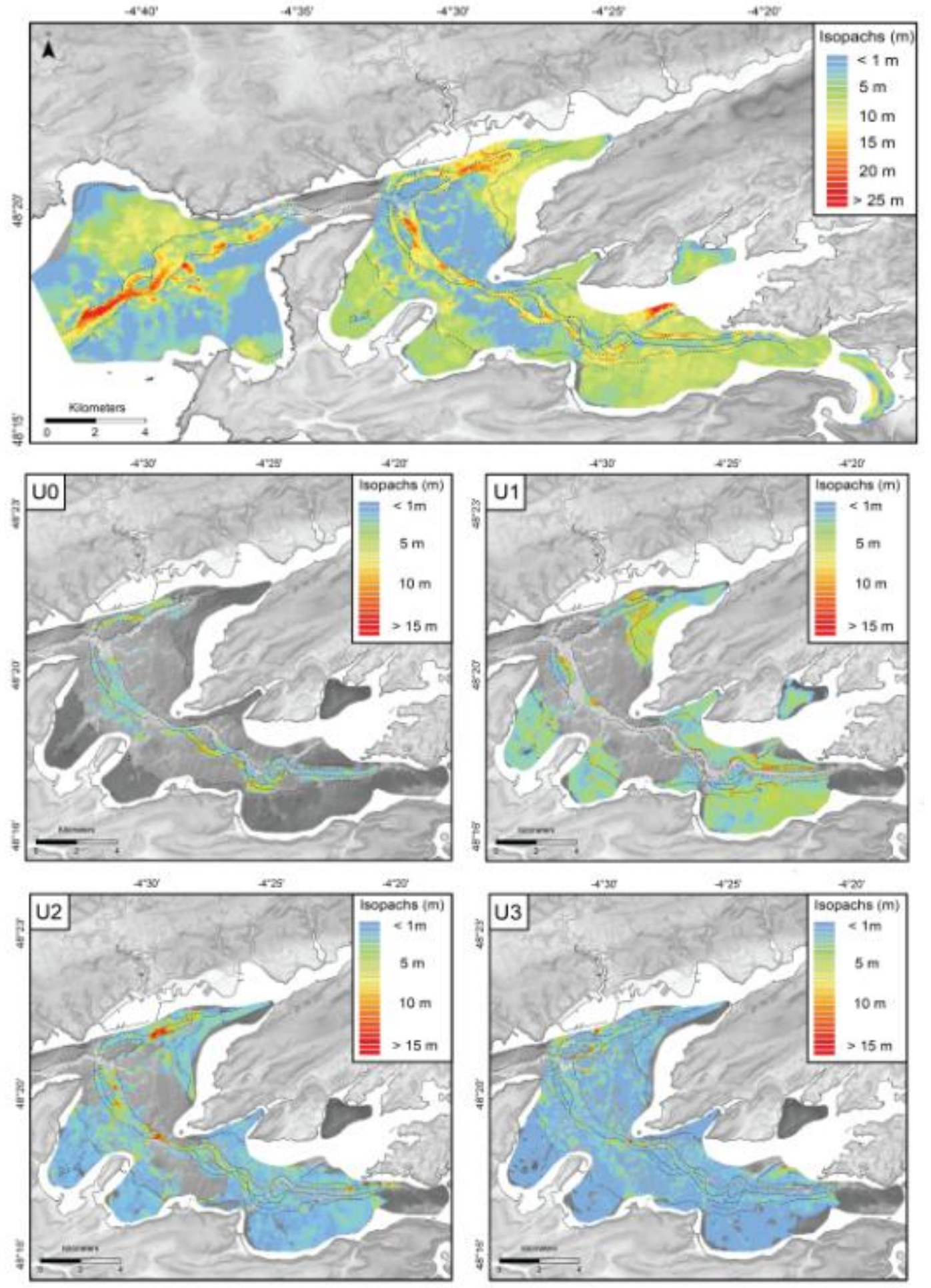

Figure 9 


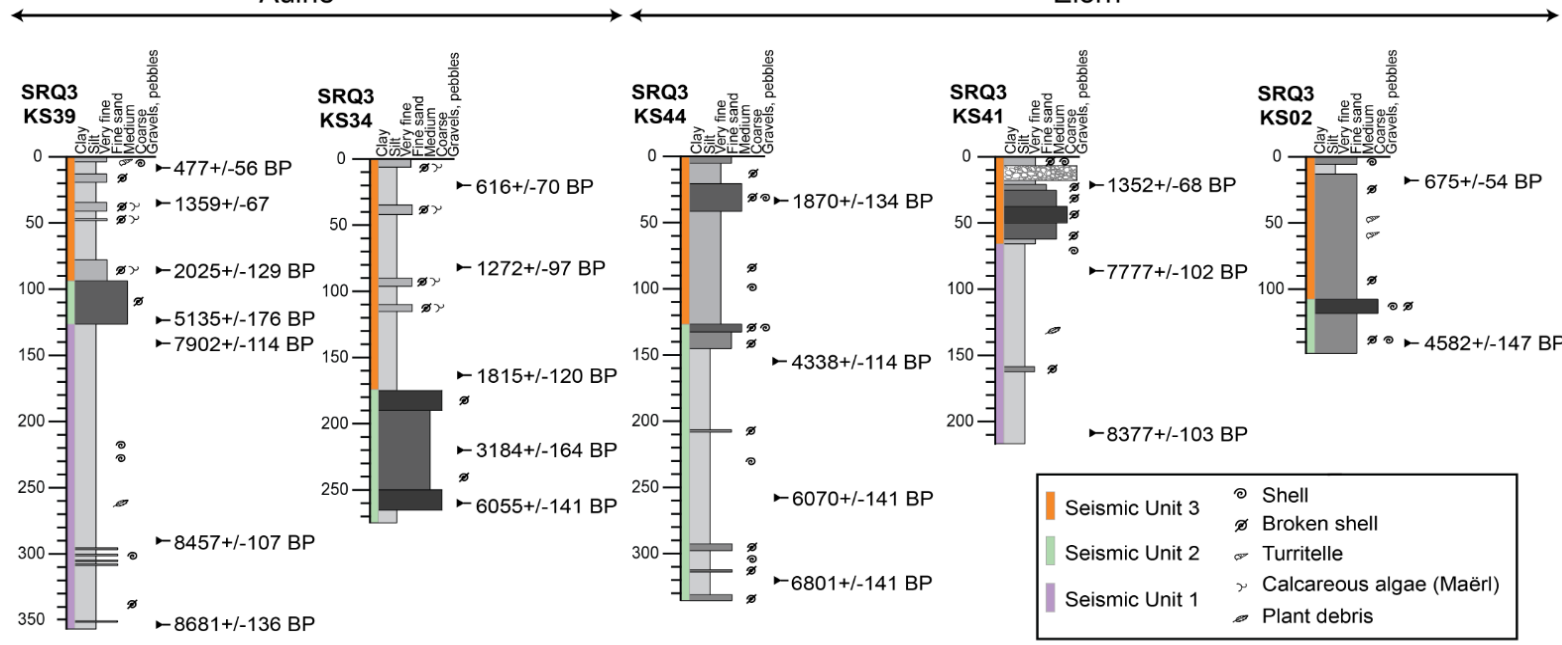

Figure 10 


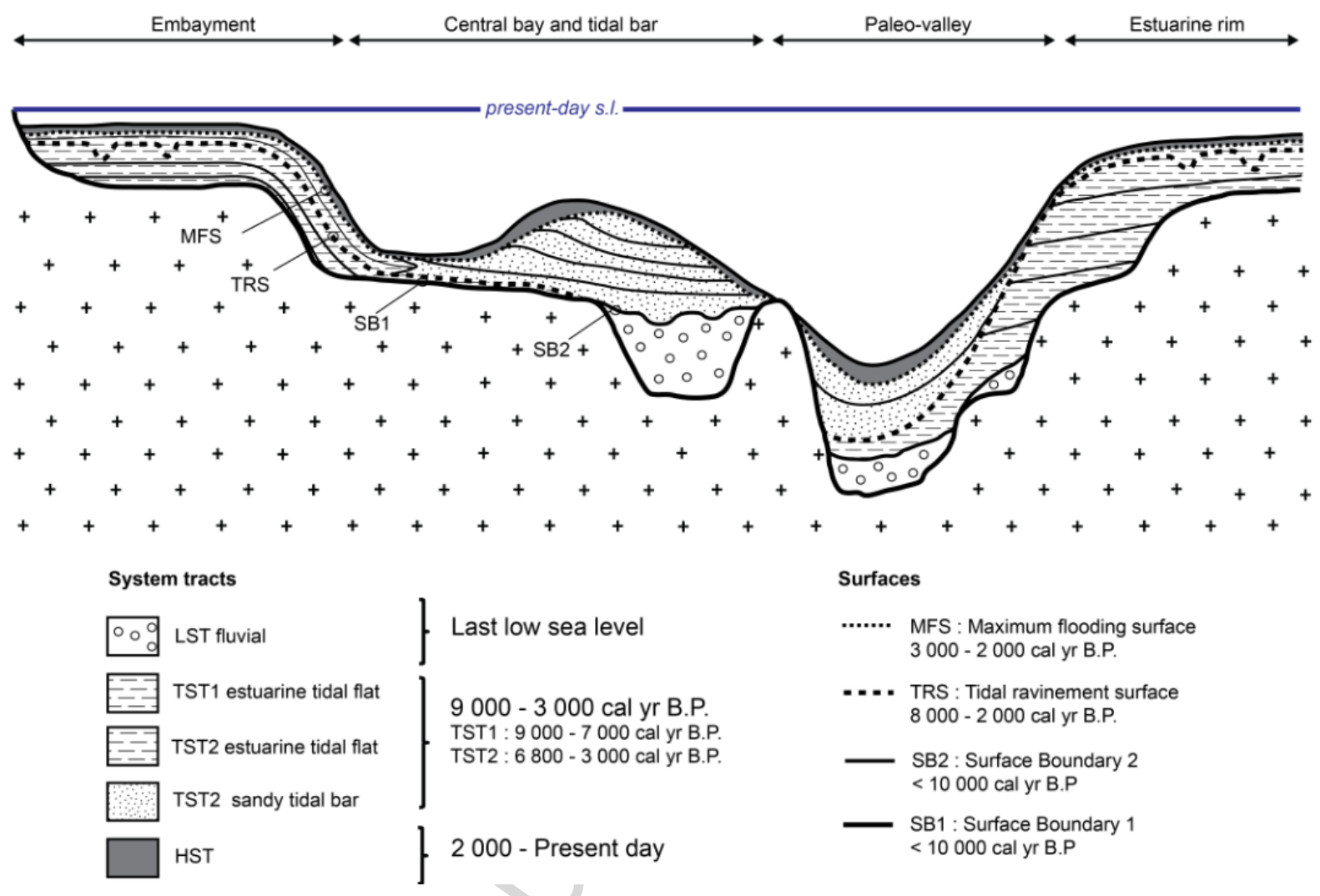

Figure 11 

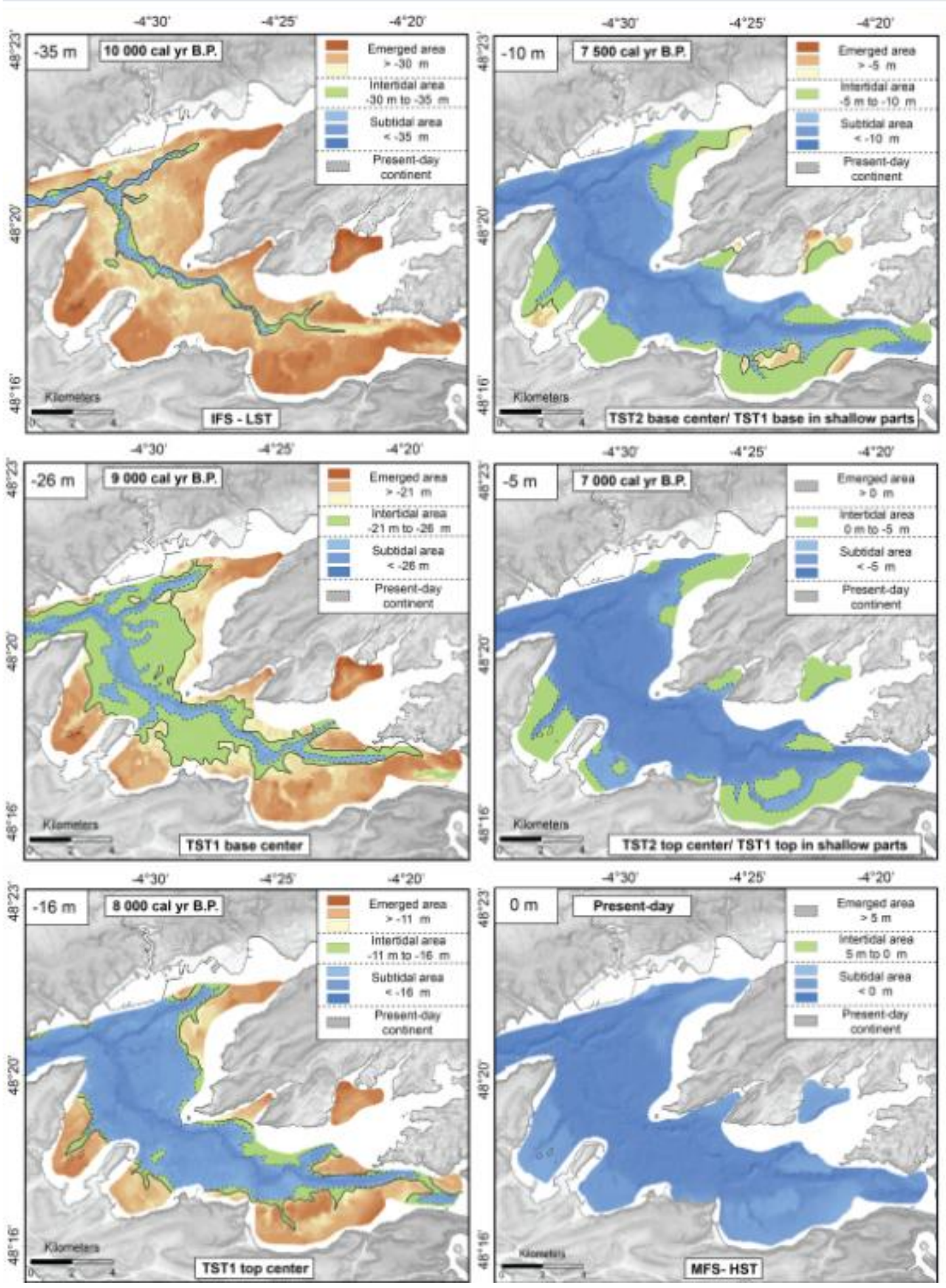

Figure 12 

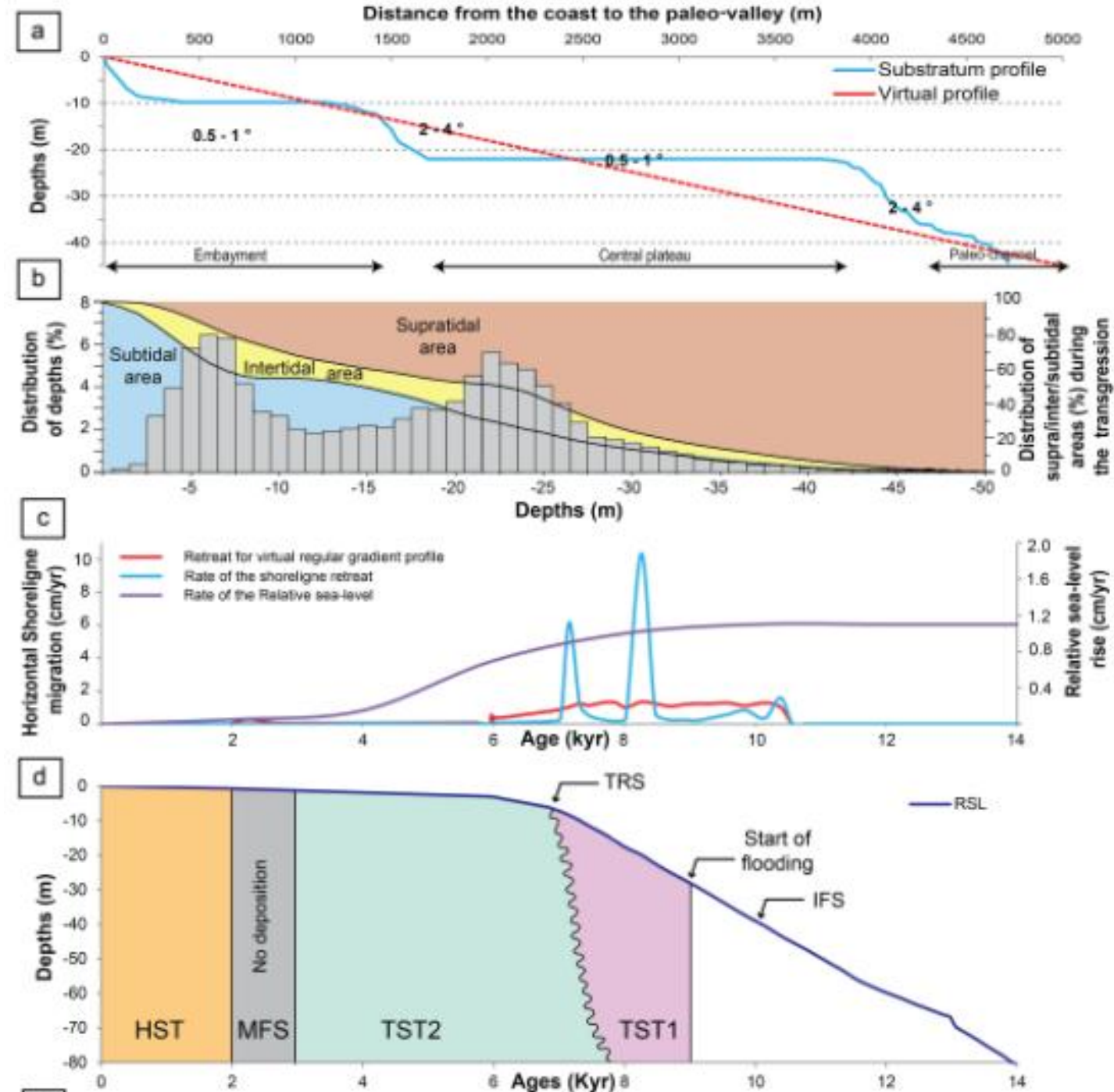

e

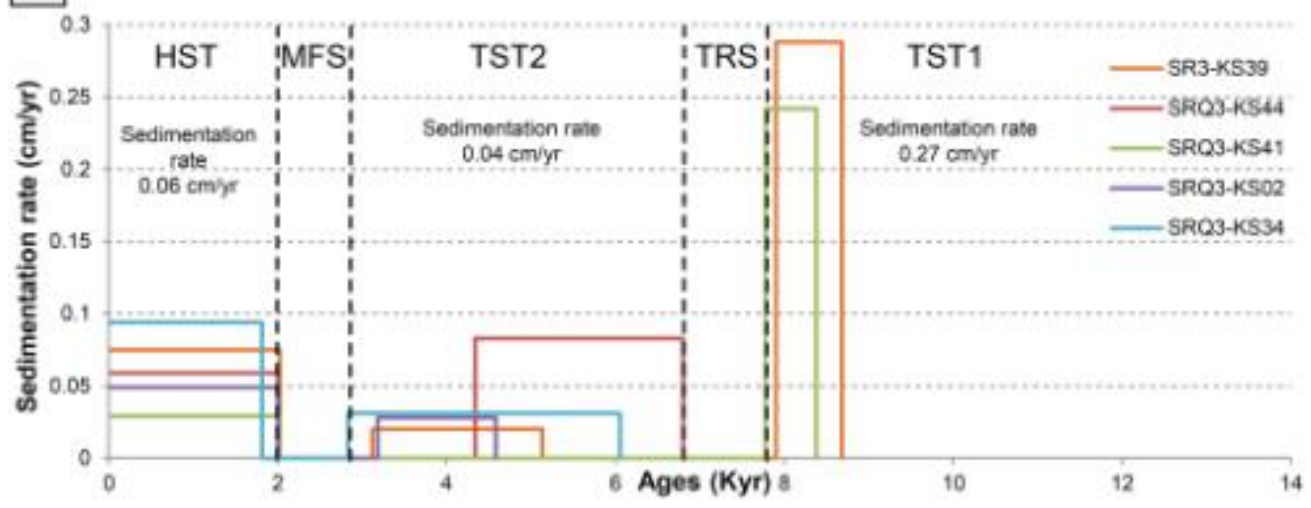

Figure 13 
Table 1

\begin{tabular}{|c|c|c|c|c|c|c|c|c|c|c|}
\hline Core label & $\begin{array}{c}\text { Depth } \\
\text { (cm) }\end{array}$ & $\begin{array}{c}\text { Lab. } \\
\text { Number }\end{array}$ & Species & $\begin{array}{l}{ }^{14} \mathrm{C} \text { age } \\
(\mathrm{yr} \text { BP) }\end{array}$ & $\begin{array}{c}\text { error } \\
(1 \sigma)\end{array}$ & $\begin{array}{c}\text { Reservoir } \\
\text { correction }^{\mathrm{a}} \\
\left({ }^{14} \mathrm{C} \text { yr }\right)\end{array}$ & $\begin{array}{c}\text { error }^{a} \\
(1 \sigma)\end{array}$ & $\begin{array}{c}{ }^{14} \mathrm{C} \text { age } \\
\text { corrected } \\
\text { for } \\
\text { reservoir } \\
\left({ }^{14} \mathrm{C} \text { yr BP }\right)\end{array}$ & $\begin{array}{c}\text { error }^{c} \\
(1 \sigma)\end{array}$ & $\begin{array}{l}\text { Calendar } \\
\text { age range }^{d} \\
(\text { yr BP, 2 } \sigma)\end{array}$ \\
\hline SRQ3-KS02 & 35 & Poz-76836 & bulk bentic & 1025 & 30 & 325 & 46 & 700 & 55 & $621-729$ \\
\hline SRQ3-KS02 & 92 & Poz-76860 & marine shell & 4410 & 40 & 325 & 46 & 4085 & 61 & $4435-4729$ \\
\hline SRQ3-KS34 & 20 & Poz-76814 & bulk bentic & 990 & 30 & 325 & & 665 & 55 & $546-686$ \\
\hline SRQ3-KS34 & 80 & Poz-76816 & marine shell & 1670 & 30 & 325 & 46 & 1345 & 55 & $1175-1368$ \\
\hline SRQ3-KS34 & 163 & Poz-76817 & marine shell & 2200 & 30 & 325 & 46 & 1875 & 55 & $1695-1935$ \\
\hline SRQ3-KS34 & 220 & Poz-76820 & marine shell & 3325 & 35 & 325 & 46 & 3000 & 58 & $3020-3347$ \\
\hline SRQ3-KS34 & 260 & Poz-76821 & bulk bentic & 5590 & 40 & 325 & 46 & 5265 & 61 & 5914-6195 \\
\hline SRQ3-KS39 & 8 & Poz-76861 & marine shell & 740 & 30 & 325 & 46 & 415 & 55 & $421-533$ \\
\hline SRQ3-KS39 & 35 & Poz-76862 & bulk bentic & 1800 & 40 & 325 & 46 & 1475 & 61 & $1292-1425$ \\
\hline SRQ3-KS39 & 73 & Poz-76863 & bulk bentic & 2250 & 40 & 325 & 46 & 1925 & 61 & 1716-1996 \\
\hline SRQ3-KS39 & 87 & Poz-76864 & marine shell & 2395 & 30 & 325 & 46 & 2070 & 55 & $1896-2154$ \\
\hline SRQ3-KS39 & 97 & Poz-76837 & marine shell & 2590 & 30 & 325 & 46 & 2265 & 55 & $2143-2357$ \\
\hline SRQ3-KS39 & 121 & Poz-76838 & bulk bentic & 4810 & 40 & 325 & 46 & 4485 & 61 & 4959-5311 \\
\hline SRQ3-KS39 & 130 & Poz-76840 & marine shell & 7410 & 40 & 325 & 46 & 7085 & 61 & 7788-8016 \\
\hline SRQ3-KS39 & 290 & Poz-76842 & bulk bentic & 7970 & 50 & 325 & 46 & 7645 & 68 & $8350-8563$ \\
\hline SRQ3-KS39 & 307 & Poz-76843 & bulk bentic & 8010 & 40 & 325 & 46 & 7685 & 61 & $8361-8585$ \\
\hline SRQ3-KS39 & 347 & Poz-76849 & marine shell & 8200 & 50 & 325 & 46 & 7875 & 68 & $8545-8817$ \\
\hline SRQ3-KS41 & 25 & Poz-76832 & bulk bentic & 1780 & 30 & 325 & 46 & 1455 & 55 & $1284-1419$ \\
\hline SRQ3-KS41 & 77 & Poz-76833 & marine shell & 7280 & 40 & 325 & 46 & 6955 & 61 & $7675-7879$ \\
\hline SRQ3-KS41 & 210 & Poz-76834 & bulk bentic & 7890 & 50 & 325 & 46 & 7565 & 68 & $8274-8479$ \\
\hline SRQ3-KS44 & 35 & Poz-76826 & marine shell & 2275 & 30 & 325 & 46 & 1950 & 55 & 1736-2004 \\
\hline SRQ3-KS44 & 150 & Poz-76827 & marine shell & 4245 & 35 & 325 & 46 & 3920 & 58 & $4224-4451$ \\
\hline SRQ3-KS44 & 250 & Poz-76828 & marine shell & 5590 & 40 & 325 & 46 & 5265 & 61 & 5914-6195 \\
\hline SRQ3-KS44 & 260 & Poz-76830 & marine shell & 5620 & 40 & 325 & 46 & 5295 & 61 & 5929-6211 \\
\hline SRQ3-KS44 & 320 & Poz-76831 & marine shell & 6280 & 40 & 325 & 46 & 5955 & 61 & $6660-6941$ \\
\hline
\end{tabular}

a: Reservoir correction infered from Tisnérat-Laborde et al. (2010).

b: Corrected ${ }^{14} \mathrm{C}$ ages are obtained by subtracting the reservoir correction to the original ${ }^{14} \mathrm{C}$ age

c: Errors associated to the corrected ${ }^{14} \mathrm{C}$ were propagated through the quadratic sum

$\mathrm{d}$ : Corrected ${ }^{14} \mathrm{C}$ ages were then calibrated using the atmospheric calibration curve IntCal13 (Reimer et al., 2013) 